17

\title{
Fish Discards Management: Pollution Levels and Best Available Removal Techniques
}

\author{
Luis T. Antelo*, Carla Lopes, Amaya Franco-Uría, Antonio A. Alonso \\ Process Engineering Group, Marine Research Institute IIM-CSIC \\ Eduardo Cabello, 6 - 36208 Vigo, Spain.
}

\footnotetext{
*Corresponding author. Telf.: 34986231930

E-mail address: ltaboada@iim.csic.es
} 


\section{Abstract}

41 Fish discards and by-catch issues are highly topical subjects nowadays permanently under a social focus. To manage this issue, two main approaches are being considered to address this discard problem: reducing by-catch and increasing by-catch utilization. As these two harvesting strategies may be complementary, an appropriate balance between by-catch reduction and utilization is desirable for any fishery. Increased by-catch valorization interest may come from a greater demand for fish products: the development of new markets for previously discarded species; the use of low-value by-catch specimens for aquaculture and animal feed or the creation of valueadded fish products from by-catch or discarded fish for food, pharmaceutical or cosmetic industries. In this valorization framework, and always targeting the aim of promoting the responsible and sustainable management of marine resources, pollutant levels in catches of European fisheries (including target and main discarded species), as well as the best available decontamination techniques of marine valorized discards/byproducts are compiled and analyzed in this work. This is due to the fact that a wide different distribution of pollutant concentration between tissues in fish can be found, especially in detoxifying organs, like kidney and liver and in other fractions of high lipid content, like skin. Therefore, contaminants present in fish discards may be transferred to the valorized products obtained from them, leading to possible long-term bioaccumulation and subsequent adverse health effects.

60 The objective of the present work is to provide a general view of the present 61 discards/by-catch valorization-based management options.

63 Keywords Fish discards; sustainability; pollutants; removal techniques; valorization 


\section{Introduction}

Most of Persistent Organic Pollutants (POP) and heavy metals emitted to air or water as products or by-products of industrial activities, or applied directly on land (i.e. pesticides) can travel long distances from its primary source, and can finally end up in the marine environment $(1,2)$. Most common examples of these substances are polychlorinated dibenzo-p-dioxins (PCDD) and dibenzofurans (PCDF), polychlorinated biphenyls (PCB), polycyclic aromatic hydrocarbons (PAH), organochlorine pesticides (OCP) (like hexachlorobenzene - HCB, hexachlorocyclohexanes - HCHs, dichlorodiphenyltrichloroethane - DDTs, and metabolites like dichlorodiphenyldichloroethylene - DDE), polybrominated diphenyl ethers (PBDE), hexabromocyclododecanes (HBCDs) and metals like $\mathrm{As}, \mathrm{Cu}, \mathrm{Cd}, \mathrm{Zn}, \mathrm{Pb}$ and $\mathrm{Hg}$. Due to their persistence and toxicity, they can accumulate in biota and biomagnify through trophic webs, being biomagnification especially important for aquatic organisms $(3,4)$.

Many studies in the scientific literature, like surveys of fish and fish products in markets of different countries (5-8), monitoring reports of Public Administrations and the EU (9), as well as web tools like the EcosystemData of ICES (http://ecosystemdata.ices.dk/), reported significant levels of this kind of pollutants (especially of dioxins, PCBs and heavy metals) in several cases for commercial species of different fisheries. Many of these studies have been developed in heavily polluted areas like the Baltic and North Seas (10-12). Hence, it is logical to assume the presence of contaminants in other non-commercial species, although contamination levels in these non-targeted and/or discarded species are not usually assessed. However, a sustainable management of discards passes through the evaluation of their pollutant content, since the most common uses of discards are oriented to both the production of fish oil and meal (for aquaculture/animal feeds) or as additives in human direct consumption products (food supplement, margarines, gelatine, etc.). In fact, pollutant 
amounts found in some marine valorized by-products are of concern (13). On the other hand, some studies revealed that concentration of POPs is significantly higher in farmed fish (mainly salmon) than in wild fish (14-16). This is due to the presence of pollutants in feed, which comprise fish oil and meal (17). Concerns on this issue have led EU to set maximum levels for dioxins and dioxin-like (DL-) PCBs for aquaculture feeds (18), fish and fish products (19)

For fulfilling these regulations, different options are available to the fish farming industry. One possibility is to use fish oils or meals presenting low levels of these pollutants for fish feed, for example, from the southern hemisphere (20). However, this is not the optimal approach, since fish oil availability is already limited (21). Another

100 solution is to employ vegetable oils in the feed, but these oils do not contain the fatty 101 acids that represent the positive nutritional properties of marine food, and thus, fish breeding with vegetable oils results in specimens with worse performance, health and quality. In fact, a mixture of oils is usually employed as compromise solution

$104(20,22,23)$. Finally, pollutants could be removed from the oils and meals used in fish 105 feeds, while retaining the nutritive components of the oil (21). Therefore, research and 106 development of technologies for the removal of these contaminants has gained considerable importance (17), since market demand for decontaminated fish feeds in aquaculture has increased during last years (20). Most studies on pollutant removal techniques are focused on the reduction/elimination of POPs (dioxins and dioxin-like

110 polychlorinated biphenyls) in fish oils, especially those produced for salmon breeding.

111 Less attention has been paid to fishmeal, and none to other valorized fish products, like 112 gelatin or hydrolizates. Taking into account the lipophilic character of pollutants, their 113 levels on this type of proteic products should not be of concern.

114 In the aim of promoting the responsible and sustainable management of the 115 European fishing activity, actions were directed to the development of policies to reduce 
116 unwanted by-catches and eliminate discards in European fisheries, as well as to make

117 the best possible use of the captured resources avoiding its waste. In this sustainability

118 framework, FAROS project, co-funded under the LIFE+ Environmental Program of the

119 European Union (LIFE08 ENV/E/000119 - www.farosproject.eu), aims as one of its

120 main objectives to analyze the valorization potential of fish discards in order to

121 contribute to their sustainable management by minimizing discards/by-catch through

122 their optimal valorization to recover and to produce valuable chemicals of interest in the

123 food and pharmaceutical industry (24). In order to properly define these adding-value

124 processes, the key issues of pollutant levels in catches of European fisheries (including 125 target and main discarded species), as well as the best available decontamination

126 techniques of marine valorized by-products were compiled and analyzed from several

127 studies, with the objective of providing a general picture of the present management 128 options.

\section{2. Pollutant content in species of European fisheries}

$131 \quad$ 2.1. Existing pollutant profiles

132 To date, Ecosystemdata web tool of ICES (http://ecosystemdata.ices.dk/) can be 133 considered one of the most complete infrastructure of marine data compilation 134 corresponding to the European fishing area. A search within this database was 135 developed for all the discarded species (159) identified in the fisheries considered in 136 FAROS project (25):

137 a) Galician bottom otter trawl fleet vessels authorized to fish in Community waters 138 targeting flat fish, and basically operating in Great Sole Bank.

139 b) Galician coastal bottom otter trawl fleet vessels targeting a variety of demersal $140 \quad$ species. 
c) Portuguese coastal bottom trawl vessels for demersal fish that operate along the year, with hauls directed to a variety of species.

143 The objective was to check which "FAROS species" (main discarded species in

144 these fisheries) were found in the database, and if present, which ones were monitored 145 on pollutant profiles. The qualitative results of this query are shown in Table S1 of the 146 Supplementary Material. It can be seen that pollutant analyses are only available for 25 147 of the 159 species reviewed. Among these 25 species, only 7 correspond to the 29 main 148 species discarded in the Spanish and Portuguese métiers, marked on grey in Table S1

149 (25). These species are: Chimaera monstrosa (rabbit fish), Lepidorhombus whiffiagonis 150 (megrim), Melanogrammus aeglefinus (haddock), Merluccius merluccius (hake), 151 Micromesistius poutassou (blue whiting), Scomber scombrus (Atlantic mackerel) and 152 Scyliorhynus canicula (small-spotted catshark). Moreover, Micromesistius poutassou and Scyliorhynus canicula were only monitored for heavy metals and $\mathrm{Hg}$ alone, 154 respectively. The remaining 18 pollutant-monitored species included in Table S1 are 155 considered as discards in these métiers only in few occasions, i.e., at a very low discard 156 rate. In fact, most of them have an important commercial value, hence the reason of 157 their exhaustive monitoring on pollutants. Examples of these species are Gadus morhua 158 (cod), Merluccius merluccius (hake), Coryphaenoides rupestris (roundnose grenadier), 159 Hoplostethus atlanticus (orange roughy) or Lophius piscatorus (monkfish). Besides, 160 flatfish or species that live on or within the sediment layer (bottom dwelling fish) and 161 deep sea fish are among the monitored species, not only because of its commercial 162 value, but also because they are known to highly bioaccumulate pollutants. Examples 163 are Brosme Brosme (tusk), Coryphaenoides rupestris (roundnose grenadier), 164 Glyptocephalus cynoglossus (witch flounder), Hippoglossoides platessoides (American 165 plaice), Microstomus kitt (lemon sole) or Pleuronectes platessa (European plaice). This 166 type of species lives on the sediment layer at the sea bottom (benthic organisms), and 
167 directly uptake contaminants from sediment particles apart from diet $(26,27)$. Pollutants

168 tend to be associated with organic matter due to their lipophilic character (3), and at the

169 same time, organic matter is bound to suspended particles in the water column that end

170 up in the sediment layer (marine snow) (28). Moreover, deep water fish have a

171 significant potential for the accumulation of POPs because many of the deep water

172 species feed at higher trophic levels and live longer than pelagic fish (29).

173 2.2. Pollutant levels in discarded FAROS species

174 A review of studies presenting the quantitative pollutant contents in fish was

175 developed. Values of either heavy metals and/or POPs (PCDD/Fs, PCBs and OCPs) in

176 European commercial species are reported in Tables 1 and 2. These commercial species

177 are considered as discards in Great Sole Bank and Atlantic Spanish and Portuguese

178 coast métiers (although most of them usually at a very low rate) for different reasons.

179 The main ones are: i) legal reasons related to the quota system; ii) strategic or

180 commercial reasons; iii) lack of quality in the case of damaged specimens or in poor

181 condition; etc (25).

182 Data were collected from market surveys in different countries and from other

183 relevant studies available on commercial fish species (flesh or viscera). Origin was also

184 included when possible. Although many studies on pollutant monitoring are available

185 for the area of the Baltic Sea, they were not included in Tables 1 and 2 since the species

186 monitored (herring, cod, sprat, etc.) are different from those considered in the selected

187 fishing area (Great Sole Bank and coastal waters of the Atlantic side of the Iberian

188 Peninsula). Pollutant concentration values for a total of 43 species were recorded, 14 of

189 them corresponding to the most discarded species in the métiers considered in this

190 analysis (marked on grey in Tables 1 and 2).

191 In Table 1, metal concentrations present in 30 fish species identified as target and

192 main discarded on the Atlantic fisheries considered in FAROS framework are 
193 summarized. In general, a wide range of concentration values were found for all the

194 metals considered. $\mathrm{Zn}$, As and $\mathrm{Cu}$ reached the highest concentrations in the liver of 195 Aphanophus carbo. This deep sea fish presented in most of occasions the highest 196 concentrations for all metals.

197 Heavy metal bioaccumulation is related to biotic and abiotic factors such as water 198 temperature, fish biological habitat, chemical form of metal in the water, fish species, 199 gender and length or age (50). In general, it was observed that concentrations of metals 200 are significantly higher in liver tissues than in muscle for the monitored species. This is 201 particularly of concern when thinking in produce fish oil from livers. Concentration 202 values ranges can vary widely among species and even for the same species in the same 203 study, which implies a clear influence of location (as expected). Among the most204 monitored species, specimens of Aphanophus carbo (black scabbard), Coryphaenoides rupestris (roundnose grenadier) and in less proportion Merluccius merluccius (hake), Sardina pilchardus (sardine) and Scomber scombrus (Atlantic mackerel) presented levels of pollution that can be of concern when thinking in further valorization technologies, since concentration steps are always present in these processes.

209 Concentrations of PCDD/Fs, PCBs, HCB, DDTs, chlordane, PBDEs, DDE and 210 HBCD are shown in Table 2. PCBS and PCDD/Fs were the most frequently analyzed 211 pollutant, due to their higher toxic effects on human health.

212 In many of the studies shown in Tables 1 and 2 , the exposure to a variety of 213 pollutants by fish ingestion was assessed $(6,7,41,42)$. The conclusions were similar in 214 most of them: moderate fish consumption not only does not pose a risk to human health 215 but also has numerous nutritional benefits. However, production of fish oil and meal 216 involves concentration processes that could increase pollutant concentration in valorized 217 products, becoming an important problem. 


\section{Pollutant removal techniques}

220

As previously mentioned, the most common uses of discards are the production of fish oil and meal. As shown in Table 3, pollutant concentration values available in the literature for fish oil and meal produced from species of different origin and location reveals that, in some cases, these levels can be of concern when compared to the limits established on the European Commission Directive 2006/13/EC on undesirable substances in animal feed as regards dioxins and dioxin-like PCBs (18). Therefore, purification step/s would be needed before consumption. In the next section, a revision of available decontamination techniques for fish valorized products (fish oil and meal) and other marine solid by-products is presented.

\subsection{Fish oil}

A key factor during fish oil refining is to remove contaminants without altering the levels of present nutritionally valuable compounds and the oxidative status of the oil $(54,55)$. A reduction of some type of pollutants associated to fish oil during refining has been assessed. This is due to the fact that crude fish oils are usually refined to reduce the content of free fatty acids, metal traces, pigments, etc. In particular, the deodorization step (steam distillation at high temperature and vacuum) causes a decrease not only in residual pigments and other volatile compounds, but also the almost total removal of most volatile pollutants like organochlorine pesticides $(\alpha-\mathrm{HCH}$, lindane, etc) and the reduction to a half of the initial concentration of PCBs and less volatile organochlorine pesticides (56). However, standard conditions $\left(180{ }^{\circ} \mathrm{C}\right.$ and 2 hours of contact) of

240 deodorization are found to be inefficient for the removal of dioxins and furans.

241 Most up-to-date efficient removal methodologies for fish oil involve the use of a

242 solid apolar adsorbent (like activated carbon), distillation processes, extraction 243 processes or a combination of these techniques.

244 3.1.1. Extraction with solid adsorbents 
Generally, purification of fish oil by solid adsorption is performed by mixing the oil with the adsorbent in a rotavapor under different experimental conditions, usually at

247 mild pressure and temperature. The oil is subsequently separated from the adsorbent by 248 filtration over a paper filter.

249 Eppe et al. (57) investigated oil purification by solid adsorbents for decreasing $250 \mathrm{PCDD} / \mathrm{Fs}$ and dioxin-like (DL-) PCBs levels in order to be in compliance with 251 European Legislation. The adsorbers tested were bleaching earths (polar adsorbents), acid activated silica powder, Dieatomecious earth, and several types of activated carbon (apolar adsorbents). Among the tested adsorbers, only activated carbon could significantly remove the PCDD/Fs (up to 99\%) and DL-PCBs (up to 50\%) concentration in cod liver oil. Optimum pressure and temperature of 0.05 bar and $74{ }^{\circ} \mathrm{C}$ were established, respectively. Besides, it was concluded that reaction time within the range of 10 to 50 minutes had virtually no influence on the adsorption of pollutants, while the dose of activated carbon was the most influential variable, since the higher the dose, the higher the adsorption of contaminants.

A similar study was developed by Maes et al. (55), who evaluated the efficiency of different grades and doses ( 0.1 to $0.5 \% \mathrm{ww})$ of activated carbon to remove PCDD/Fs and DL-PCBs from cod liver oil. The process was performed at reduced pressure $(0.05$ bar) and moderate temperature $\left(70{ }^{\circ} \mathrm{C}\right)$ with a 30 -minute reaction time. An almost complete elimination of PCDD/Fs and $80 \%$ removal of DL-PCBs were achieved with $0.5 \%$ of high-grade activated carbon. The lower PCBs removal was due to the minor 266 adsorption of the mono-ortho fraction (30\% or less), since their noncoplanar geometrical structure present low affinity to activated carbon.

Optimization of activated carbon adsorption for the reduction of POPs in commercial fish oil was performed by response surface methodology (58). PCDD/Fs were eliminated in a 99\%, while non-ortho PCBs and mono-ortho PCBs were reduced 
to a maximum of 87 and $21 \%$, respectively, operating at $80{ }^{\circ} \mathrm{C}$ and 15 minutes of contact time. However, PBDEs reduction was not observed with this treatment. The authors stated that an increase in the adsorption temperature will probably enhance DLPCBs reduction. However, they advise that it is necessary to have a compromise between optimal processing conditions, capacity utilisation, target Toxic Equivalent Quantity (TEQ) and oil quality specifications in large-scale industrial operations.

Usydus et al. (59) employed activated carbon at industrial scale to purify fish oil from different origins (sprat, herring and salmon). Optimum purification parameters were obtained in previous studies at laboratory scale (60), and were: dose of $1.2 \%$ weight, temperature of $85{ }^{\circ} \mathrm{C}$ and 90 minutes of contact time. Although the oil loss produced during purification was approximately $20 \%$, the removal of PCDD/Fs and dlPCBs was $77.0-99.6 \%$ and $42.7-50.0 \%$, respectively, depending on the raw material. These authors also evaluated the reduction of OCPs, PBDEs and $\mathrm{Cd}, \mathrm{Pb}$ and $\mathrm{Hg}$, which was negligible.

11 silicon-based and 9 carbon-based adsorbents were tested for the elimination of PCDD/Fs, PCBs, PBDEs, DDTs and HCBs from refined salmon oil by Ortiz et al. (61). Silicon-based adsorption was developed at $1.5 \% \mathrm{w} / \mathrm{w}, 50{ }^{\circ} \mathrm{C}$ of temperature and atmospheric pressure, according to previous studies (54). However, silicon-based adsorbents and graphitized carbon were not suitable for the removal of POPs. On the contrary, activated carbon adsorbents showed a very high removal capacity for these

291 pollutants. DL-PCBs were also better removed by activated than by graphitized carbon, 292 although efficiency was lower than in the case of PCDD/Fs (18-24\%). For the remaining POP evaluated, low effectiveness of both types of carbon-based adsorbent was observed, due to their non-planar structure. However, optimization of the adsorption process with coconut-shell activated carbon by response surface methodology resulted in an increase of the POP removal efficiencies. Operating at a 
297 dose of $2.5 \% \mathrm{w} / \mathrm{w}$ during 37.5 minutes with a temperature of $80^{\circ} \mathrm{C}$ and 1 bar resulted in

298 eliminations of 99\% PCDD/Fs, 70\% HCBs, 36\% dioxin-like PCBs, 27\% DDTs, 11\% 299 marker PCBs and 9\% PBDEs.

300 In general, activated carbon adsorption is an appropriate method for removing 301 dioxins and furans, but low elimination efficiencies are obtained for DL-PCBs. Efficient

302 activated carbon adsorption depends on a planar molecular conformation, and this will

303 strongly limit the number of possible POP to remove based on this technology (58).

304 Therefore, complete decontamination of fish oil could only be achieved by a

305 combination of activated carbon with other extraction (stripping) process $(55,62)$.

306 3.1.2. Supercritical $\mathrm{CO}_{2}$ extraction

307 Supercritical $\mathrm{CO}_{2}$ extraction (SCE) has been applied to several different processes,

308 like selective extraction of valuable natural products, separation of contaminants and 309 other processes because of its extraction selectivity, low critical point and lack of

310 flammability, toxicity and corrosiveness (17). SCE for removal of pollutants from fish

311 oil has been performed in semi-batch and counter current installations. One of the first

312 attempts of investigating the feasibility of supercritical counter current fluid extraction

313 for pollutant removal in fish oil was the study conducted by Krukonis (63). The author

314 found that PCBs can be extracted from cod oil with supercritical carbon dioxide at quite

315 modest temperature and pressure, with little yield loss of the fish oil. During the

316 experiment, temperature was held constant at $70^{\circ} \mathrm{C}$ and pressure was gradually

317 increased from 172.4 to 448.2 bar. However, it was stated that subsequent increases

318 from 241.3 bar did not increase the extractability of the pollutants. Although the results

319 obtained in this lab-scale study were promising, it was advised to subject the process to

320 a detailed economic viability evaluation, as well as to analyze factors such as stability to

321 autoxidation during storage and product performance. 
Some years later, Jakobsson et al. (64) investigated the elimination of dioxins and dibenzofurans from cod liver oil. The main objective or their study was to test the counter current method and to establish the influence of the feed oil/ $\mathrm{CO}_{2}$ ratio on the extractability of these compounds from the fish oil. The results obtained showed that the higher the carbon dioxide/oil ratio, the smaller the recovery of oil. The most effective extraction ( $80 \%$ of dioxins together with $17 \%$ of the oil) was achieved at ratios of 100 .

328 However, improvements in this technique have led to a consequent increase in pollutant removal efficiencies and to a decrease in oil loss.

Kawashima et al. (62) investigated the removal of PCDD/Fs and coplanar PCBs

331 from menhaden oil by SCE and by activated carbon adsorption. Experimental 332 conditions of SCE were $60{ }^{\circ} \mathrm{C}$ of temperature, 280 bar of pressure and a $\mathrm{CO}_{2}$ flow 333 volume of $50 \mathrm{~L} / \mathrm{g}$ oil. This method proved effective to remove PCBs, with elimination 334 percentages ranging from $70 \%$ to $90 \%$. However, removal efficiency decreases as the molecular weight of PCDD and PCDF congener increases, being in the range of 15$90 \%$ depending on the molecule. For the effective removal of high-chlorinated

$337 \mathrm{PCDD} / \mathrm{Fs}$, the authors considered an adsorption process with activated carbon. Removal

338 ratios of this process were higher than $90 \%$ for all of the isomers of $\mathrm{PCDD} / \mathrm{Fs}$, while removal percentages for PCBs were within 1\% (mono-ortho) and 30\% (non-ortho).

340 Consequently, a combined removal process (SCE with $\mathrm{CO}_{2}$ followed by activated 341 carbon adsorption) was more effective, since almost $100 \%$ of the total TEQ value was 342 reduced.

343 The same authors advanced in this field, assessing the use of continuous counter current supercritical $\mathrm{CO}_{2}$ extraction and activated carbon adsorption for removing

345 pollutants from fish oil (17). In their previous work (62), SCE was found to have high

346 efficiency in DL-PCBs removal. However, semi-batch processes require long operation

347 times, producing a purified oil yield not enough for practical use. Thus, extraction 
conditions and contaminant removal efficiency of counter current SCE was

349 investigated. As in Kawashima et al. (62), removal efficiencies decrease with an

350 increase in the molecular weights of pollutants. Process efficiency also increased with

351 extraction pressure, being the optimal operating conditions 300 bar of pressure, $70{ }^{\circ} \mathrm{C}$

352 and $\mathrm{CO}_{2} /$ oil ratio of 72 . These conditions proved effective for the remove of DL-PCBs

353 (93\%) and PCDD/Fs congeners that have molecular weights less than 400. Fish oil

354 refined by counter current SCE was subsequently treated with activated carbon for the

355 elimination of PCDD/Fs, reaching values higher than $80 \%$ for each congener. Thus, the

356 combined process reduces the pollutant concentration by $94 \%$, while presenting a

357 minimal influence on the fatty acid content of the oil. When compared with the semi-

358 batch type process, counter current SCE uses $40 \%$ less $\mathrm{CO}_{2}$ and yields $30 \%$ more

359 refined oil. However, it is necessary to consider that fish oils extracted with $\mathrm{CO}_{2}$ can

360 lose much of its unsaturation during storage and can polymerize (63).

361 3.1.3. Short-path distillation

362 Short-path distillation (SPD) technology is characterized by operation with short

363 residence times and high vacuum level. Breivik \& Thorstad (21) presented an improved

364 method based on this technology to eliminate POPs from marine oils. They found that

365 with the addition of $3-6 \%$ of an ester mixture (working fluid) prior to the distillation,

366 pollutants are removed in a much more efficient manner. In this case, the working fluid

367 was a light ethyl ester fraction of transesterified fish oil produced as a by-product from

368 commercial production of omega-3 concentrates. With this technique, concentration of

369 dioxins and PCBs were reduced by more than 90\%, including DL-PCBs. Moreover,

370 DDT, toxaphene and PBRDs were removed to a level below the analytical detection

371 limit.

372 Decontamination of sprat oil by SPD technology was evaluated by Oterhals et al.

373 (65). The objective was to quantify the effect of evaporator temperature, feed rate and 
374 addition of a working fluid (21) on the reduction of PCDD/Fs, DL-PCBs and PBDEs.

375 Furthermore, a model of SPD based on process parameters and quantitative structure 376 properties relationship was proposed by the authors to relate removal efficiency with

377 congener volatility. The results obtained in this study indicated that is not possible to 378 define optimum operation conditions for POP reduction in fish oil by SPD due to the 379 large variance in vapor pressures for the multicomponent mixture of organic 380 compounds. However, as TEQ reduction is mainly influenced by the removal of $381 \mathrm{PCDD} / \mathrm{Fs}$ and DL-PCBs, the best decontamination effect was obtained with a 382 combination of low feed rate and high evaporator temperature and working fluid 383 conditions.

384 The feedstock used in the study by Oterhals et al. (65) was the same as earlier 385 reported on activated carbon-based decontamination of fish oil (58). Therefore, these 386 authors were able to compare both removal methods. Activated carbon is an appropriate 387 method for removing compounds like PCDD/Fs, PAHs and some congeners of PCBs, 388 which present a coplanar structure, since effective adsorption is dependent on dispersive 389 electronic interactions affected by sorbate planarity and steric effects (66). However, 390 compounds like most of organochlorine pesticides and PBDEs are not adsorbed and 391 removed by this method. On the contrary, the efficiency of a SPD based 392 decontamination process is mainly dependent on the volatility of the respective 393 compounds and the selection of favorable process conditions. SPD is less influenced by 394 the conformation and chemical nature of POPs to be removed when compared to 395 activated carbon adsorption (65).

396 However, the use of SPD to eliminate POPs from fish oils will also remove other 397 volatile compounds and decrease the nutritional value and oxidative stability of the oil. 398 This fact is due to the high temperature levels $\left(>200^{\circ} \mathrm{C}\right)$ applied to the fish oil during 399 the process. Oterhals and Berntssen (67) quantified the effects of alternative SPD 
process conditions on the oil nutritional and oxidative properties and identified the optimal process conditions by combining decontamination effects in compliance with legislation levels and maximum retention of nutritional quality. Some reduction in the oxidation level was observed, but with preservation of PUFA level and quality. Only $76 \%$ of reduction of the TEQ level was achieved in the fish oil to be in accordance with international quality standards, with a final loss of vitamins lower than $20 \%$. If a higher decontamination level is required (90\%), vitamin retentions can vary between $60-90 \%$.

\subsubsection{Other procedures}

Other volatilization procedures (steam deodorization) were tested to eliminate POPs from fish oils. Carbonelle et al. (68) used a combination of an activated carbon adsorption treatment with either packed column stripping or cross-flow stripping. The

411 last two methods were introduced with the aim of improving the removal of mono-ortho

412 PCBs, since activated carbon is not adequate for this task. Packed column and cross-

413 flow stripping are procedures that involve high temperature, low pressure and injection

414 of a stripping agent (steam). Differences between them are residence time (very short in

415 packed column), pressure (pressure drop in packed column and constant in cross-flow)

416 and contact between oil and steam (counter-current in packed column). The authors 417 decided to combine cross-flow stripping (instead of packed column) with activated 418 carbon because this technique is preferable in an industrial process. With an optimum 419 combination of these methods, removal of $100 \%$ of dioxins and furans, more than $95 \%$ 420 of non-ortho PCBs and between 48 and $74 \%$ of mono-ortho PCBs was achieved. 421 However, the final nutritional quality (PUFA content, etc) of the product was not evaluated.

3.2. Fishmeal and other marine solid wastes

Although several alternatives have been tested for the elimination of pollutants from

425 fish oil, less emphasis has been given to the development of purification alternatives for 
fishmeal and marine solid by-products/wastes without decreasing its nutritional/reusable

427 value. Regarding fishmeal, decontamination techniques like ultraviolet (UV) light, 428 extraction with either organic solvents or oil, and enzymatic treatments have been 429 evaluated.

430 Baron et al. (69) applied UV on contaminated fishmeal to photodegrade dioxins. 431 After 5 days of exposure to UVB light, degradation of $70 \%$ of PCDD/Fs content was 432 obtained. However, the photodegradation mechanism triggered lipid oxidation and 433 increase the content of non- and non-ortho PCBs as reaction products in the treated 434 fishmeal. This fact, linked to the high exposure time required, make the application of 435 this methodology at industrial scale unfeasible. Although an increase in the light 436 intensity should decrease exposure time, oxidation of long-chain fatty acids would also 437 be enhanced. The authors proposed the addition of antioxidants to avoid this undesirable process.

As previously mentioned, persistent organic pollutants are lipophilic compounds, 440 and the reduction of the fat content in fishmeal will result in the concurrent reduction of 441 these undesirable compounds. Baron et al. (70) studied several techniques to remove 442 dioxin and DL-PCBs from fishmeal. The studied methods were fat extraction with organic solvents, oil, protease and direct breakdown of dioxin and PCBs using oxidoreductase. Low reduction of pollutant content was observed with fat separation after protease treatment (30\%) and with PCDD/Fs and DL-PCBs degradation by 446 oxidoreductase (10-15\%). The organic solvents (ethanol, isopropanol and isohexane) 447 reduce the fat content to $80 \%$, with a proportional reduction of pollutants, but the 448 fishmeal had a low nutritional quality and might content traces of solvents. Extraction 449 of dioxin and PCBs using olive oil or fish oil resulted in $60 \%-75 \%$ of decontamination 450 effect. Enrichment of the oily phase in pollutants was observed for all congeners and 451 both oil types. Increasing the time of extraction ( 24 hours) only resulted in a minor 
452 increase in the levels of POPs in oils, indicating that equilibrium and partitioning of the 453 contaminant into the oil is a fast process (70). Oterhals and Nygard (71) also 454 investigated the reduction of persistent organic pollutants in fishmeal at pilot scale by 455 organic solvent and soybean oil extraction. Both extraction agents provided fishmeal 456 products with a TEQ value below the maximum permitted levels. However, lowest 457 levels were observed with soybean oil (reduction of $97 \%$ of TEQ). Moreover, the 458 estimated fat content of the extracted product presented a value close to the respective 459 one in ordinary processed fishmeal. This was considered as a critical success factor if 460 the process should be used in industrial application. The obtained decontamination rates 461 in this work were higher than those reported by Baron et al. (70) on the basis of olive oil 462 extraction. According to Oterhals and Nygard (71), the difference might be explained by 463 the combined use of a higher extraction temperature $\left(88^{\circ} \mathrm{C}\right.$ vs room temperature) and 464 oil/matrix ratio (1:3 vs 1:1). From the industrial point of view, the oil extraction process 465 has several advantages when compared to organic solvent extraction, like for example, 466 easy integration in an existing fishmeal processing line and the use of a safe and non467 flammable extraction medium.

468 Other type of pollutants found in marine solid by-products are metals. Removal of 469 these compounds from the solid matrix is critical for its subsequent reuse and 470 valorization as fodder. Tavakoli and Yoshida (72) investigated the use of sub- and 471 supercritical water treatment as a method for recovering heavy metals from squid 472 wastes. Reaction temperature ranged between 443 and $653 \mathrm{~K}$ and the pressure range 473 between 7.92-300 bar, and produced four phases (unreacted solid, aqueous, fat and oil). 474 Distribution coefficients of the metals considered $(\mathrm{Cd}, \mathrm{Cu}$ and $\mathrm{Zn})$ followed the 475 decreasing order fat $>$ solid $>$ oil $>$ aqueous phase. The proposed decontamination waste 476 process is energy efficient according to the authors, and produces valuable products (oil, 477 soluble proteins, organic acids and aminoacids) from waste. In addition, metal ions can 
478 be recovered from waste streams and recycled back to the related industries. Other

479 techniques for the removal of metals from marine by-products involve a coagulation 480 process. Ghimire et al. (73) proposed an environmental friendly removal process of 481 heavy metals from Cd-contaminated scallop waste by using apple waste and astringent 482 persimmon extract (kaki-shibu), which has the advantage of a coagulating effect 483 independent of $\mathrm{pH}$. The process consists of three steps: 1) leaching of all metals 484 contained in scallop waste by dilute sulphuric acid; 2) removal by kaki-shibu 485 coagulation of turbid organic materials from the leach liquor and; 3) adsorption of 486 heavy metals onto a gel prepared with apple waste. To adjust $\mathrm{pH}$ (lower in the leaching 487 process and higher during the adsorption), the authors proposed a counter current 488 process, recycling the leach liquor to the feed waste. The obtained cadmium free scallop waste can be used as cattle and fish fodder, while the cadmium free apple waste can be reused as fertilizer.

Discards are one of the most important topics in fisheries, both from an economic and environmental point of view. The contribution to a sustainable management of this 493 biomass through their optimal valorization highly depends on the quality of the products 494 to be obtained from them. The products of discard valorization are mainly concentrates, being the most common ones fish oil and meal. Pollutants contained in the raw material are usually present at higher concentrations in the valorized product, especially if the 497 product has a high fat content (oil). Therefore, reduction and/or elimination of 498 undesirable and toxic compounds from fish oil and fishmeal is a key factor for its safe 499 reuse, either as feed in aquaculture or as additive in food products.

500 Three techniques are currently available to reduce POPs from fish oil: 1) solid 501 adsorbers (activated carbon), 2) SCE and, 3) SPD. Although SPD remove a wider 502 variety of pollutants (PCDD/Fs, DL-PCBs, PBDEs, OCPs) than SCE or activated 503 carbon adsorption, this technique is performed under experimental conditions 
504 (especially of temperature) that can affect the positive properties of the oil if a high

505 degree of decontamination is needed. SCE has a minimal environmental impact and 506 preserve the PUFA content of the treated oil, although some authors found unstable

507 behavior of the oil during storage. However, it is not efficient for the removal of high-

508 chlorinated PCDD/Fs, and for that reason, can be combined with activated carbon

509 adsorption, that effectively removes dioxins and furans. The selection of the most

510 appropriate technique for oil decontamination mainly depends on the pollutant type and

511 congener found in the oil, and the percentage of TEQ value reduction needed to comply

512 with legislation, which is different according to the final use (feed or food). Regarding

513 fishmeal, the most effective method to remove pollutants is the reduction of the fat

514 content. Extraction or separation of fat content can be achieved by extraction with

515 organic solvent and oil, or with enzymatic treatment. The most promising method so far

516 is the extraction with oil (olive, soybean, etc.), which does not alter the nutritional

517 properties of the meal and does not involve the use of toxic solvent. For metal

518 elimination, critical extraction or coagulation methods can be used.

519 As stated, the assessment of pollution levels in fish and the application of removal

520 techniques when necessary is a key factor for an effective discards management.

521 Nonetheless, more alternatives apart from fish oil and meal must be provided to the

522 processing sector in order to optimize the reuse of the different species by the

523 production of high-added value products. Hence, valorizing potential of the most

524 discarded species in FAROS project will be evaluated in the second part of this work.

525 The potential presence of contaminants will be discussed in terms of valorization 526 process of the different species.

528 Acknowledgement 
529 The authors acknowledge the financial support received from the LIFE+ Program of the

530 European Union (FAROS Project - LIFE08 ENV/E/000119). The authors want also to

531 acknowledge the intense work carried out by the different research groups belonging to

532 FAROS partners.

533

534 Supporting Information Available

535 Availability of pollutant monitoring data for discarded species in Spanish and 536 Portuguese fisheries is shown in Table S1.

\section{$538 \quad$ Literature cited}

539 (1) Ling, H.; Diamond, M.; Mackay, D. Application of the QWASI

540 fugacity/aquivalence model to assessing sources and fate of contaminants in 541 Hamilton Harbour. J. Great Lakes Res. 1993, 19, 582-602.

542 (2) Wania, F.; Breivik, K.; Persson N.J.; McLachlan, M.S. CoZMo-POP 2 - A fugacity543 based dynamic multi-compartmental mass balance model of the fate of persistent $544 \quad$ organic pollutants. Environ. Modell. Softw. 2006, 21, 868-884.

545 (3) Mackay, D.; Fraser, A. Bioaccumulation of persistent organic chemicals: 546 mechanisms and models. Environ. Pollut. 2000, 110, 375-391.

547 (4) Storelli, M.M. Potential human health risks from metals ( $\mathrm{Hg}, \mathrm{Cd}$, and $\mathrm{Pb}$ ) and 548 polychlorinated biphenyls (PCBs) via seafood consumption: estimation of target 549 hazard quotients (THQs) and toxic equivalents (TEQs). Food Chem. Toxicol. 2008, $550 \quad 46,2782-2788$.

551 (5) Karl, H.; Ruoff, U.; Blüthgen, A. Levels of dioxins in fish and fishery products on 552 the German market. Chemosphere 2002, 49, 765-773. 
553 (6) Falcó, G.; Llobet, J.M.; Bocio, A.; Domingo, J.L. Daily intake of arsenic, cadmium, 554 mercury, and lead by consumption of edible marine species. J. Agric. Food Chem. 2006, 54, 6106-6112.

556 (7) Miklavcic, A.; Stibilj, V.; Heath, E.; Polak, T.; Tratnik, J.S.; Klavz, J.; Mazej, D.;

557 Horvat, M. Mercury, selenium, PCBs and fatty acids in fresh and canned fish available on the Slovenian market. Food Chem. 2011, 124, 711-720.

559 (8) Vieira, C.; Morais, S.; Ramos, S.; Delerue-Matos, C.; Oliveira, M.B.P.P. Mercury, 560 cadmium, lead and arsenic levels in three pelagic fish species from the Atlantic 561 Ocean: Intra- and inter-specific variability and human health risks for consumption. $562 \quad$ Food Chem. Toxicol. 2011, 49, 923-932.

563 (9) OSPAR. Quality Status Report 2010. OSPAR Commission, London, UK. 176 pp. 5642010.

(10) Kiviranta, H.; Vartiainen, T.; Parmanne, R.; Hallikainen, A.; Koistinen, J. PCDD/Fs and PCBs in Baltic herring during the 1990s. Chemosphere 2003, 50,

(11) Knutzen, J.; Bjerkeng, B.; Næs, K.; Schlabach, M. Polychlorinated 2010, 78, 695-700.

(13) Rawn, D.F.K.; Breakell, K.; Verigin, V.; Nicolidakis, H.; Sit, D.; Feeley, M.; Ryan, 
polychlorinated dibenzo-p-dioxins, dibenzofurans, and polybrominated diphenyl

579 ethers. J. Food Sci. 2009, 74, 31-36.

580 (14) Hites, R.A.; Foran, J.A.; Carpenter, D.O.; Hamilton, M.C.; Knuth, B.A.; Schwager,

581 S.J. Global assessment of organic contaminants in farmed salmon. Science 2004, $582 \quad 303,226-229$.

583 (15) Hamilton, M.C.; Hites, R.A.; Foran, J.A.; Schwager, S.J.; Knuth, B.A.; Carpenter,

584 D.O. Lipid composition and contaminants in farmed and wild salmon. Environ. Sci. Technol. 2005, 39, 8622-8629.

586 (16) Shaw, S.D.; Brenner, D.; Berger, M.L.; Carpenter, D.O.; Hong, C.S.; Kannan, K.

587 PCBs, PCDD/Fs, and organochlorine pesticides in farmed Atlantic salmon from 588 Maine, eastern Canada, and Norway, and wild salmon from Alaska. Environ. Sci.

589 Technol. 2006, 40, 5347-5354.

590 (17) Kawashima, A.; Watanabe, S.; Iwakiri, R.; Honda, K. Removal of dioxins and 591 dioxin-like PCBs from fish oil by countercurrent supercritical $\mathrm{CO}_{2}$ extraction and 592 activated carbon treatment. Chemosphere 2009, 75, 788-794.

593 (18) Commission Directive 2006/13/EC of 3 February 2006 amending Annexes I and II 594 to Directive 2002/32/EC of the European Parliament and of the Council on undesirable substances in animal feed as regards dioxins and dioxin-like PCBs. Off. J. Eur. Communities 2006a, L32, 44-53.

597 (19) Commission Regulation (EC) No 1881/2006 of 19 December 2006 setting maximum levels for certain contaminants in foodstuffs. Off. J. Eur. Communities

600 (20) Pratoomyot, J.; Bendiksen, E.Å.; Bell, J.G.; Tocher, D.R. Comparison of effects of 601 vegetable oils blended with southern hemisphere fish oil and decontaminated 602 northern hemisphere fish oil on growth performance, composition and gene 603 expression in Atlantic salmon (Salmo salar L.). Aquaculture 2008, 280, 170-178. 
604 (21) Breivik, H.; Thorstad, O. Removal of organic environmental pollutants from fish 605 oil by short-path distillation. Lipid Technol. 2005, 17, 55-58.

606 (22) Berntssen, M.H.G.; Julshamn, K.; Lundebye, A.-K. Chemical contaminants in 607 aquafeeds and Atlantic salmon (Salmo salar) following the use of traditional- versus 608 alternative feed ingredients. Chemosphere 2010, 78, 637-646.

609 (23) Sprague, M.; Bendiksen, E.A.; Dick, J.R.; Strachan, F.; Pratoomyot, J.; Berntssen, 610 M.H.G.; Tocher, D.R.; Bell, J.G. Effects of decontaminated fish oil or a fish and 611 vegetable oil blend on persistent organic pollutant and fatty acid compositions in 612 diet and flesh of Atlantic salmon (Salmo salar). Brit. J. Nutr. 2010, 103, 1442-1451.

613 (24) Alonso, A.; Antelo, L.; Otero, I.; Pérez, R. Contributing to fisheries sustainability 614 by making the best possible use of their resources: the BEFAIR initiative. Trends $615 \quad$ Food Sci. Tech. 2010, 21, 569-578.

616 (25) Pérez, N.; Prista, N.; Bellido, J.; Fernandes, A.C.; Azevedo, M.; Santos, J.; 617 Fernández, J. Manual on the strategies and solutions on board to reduce discards. 618 FAROS Document 1.2. Available at http://www.farosproject.eu/documentos.aspx. 6192011.

620 (26) Berge, J.A.; Brevik, E.M. Uptake of metals and persistent organochlorines in crabs 621 (Cancer pagurus) and flounder (Platichthys flesus) from contaminated sediments: mesocosm and field experiments. Mar. Pollut. Bull. 1996, 33, 46-55.

623 (27) Sakurai, T.; Kobayashi, J.; Imaizumi, Y.; Suzuki, N. Non-food-chain transfer of 624 sediment-associated persistent organic pollutants to a marine benthic fish. Mar. $625 \quad$ Pollut. Bull. 2009, 58, 1072-1077.

626 (28) Froescheis, O.; Looser, R.; Cailliet, G.M.; Jarman, W.M.; Ballschmiter, K. The 627 deep-sea as a final global sink of semivolatile persistent organic pollutants? Part I: 628 PCBs in surface and deep-sea dwelling fish of the North and South Atlantic and the 629 Monterey Bay Canyon (California). Chemosphere 2000, 40, 651-660. 
630 (29) Webster, L.; Walsham, P.; Russell, M.; Neat, F.; Phillips, L.; Dalgarno, E.; Packer,

631 G.; Scurfield, J.A.; Moffat, C.F. Halogenated persistent organic pollutants in 632 Scottish deep water fish. J. Environ. Monitor. 2009, 11, 406-417.

633 (30) Mormede, S.; Davies, I.M. Heavy metal concentrations in commercial deep-sea 634 fish from the Rockall Trough. Cont. Shelf Res. 2001, 21, 899-916.

635 (31) Afonso, C.; Lourenço, H.M.; Dias, A.; Nunes, M.L.; Castro, M. Contaminant 636 metals in black scabbard fish (Aphanopus carbo) caught off Madeira and the 637 Azores. Food Chem. 2007, 101, 120-125.

638 (32) Celik, U.; Oehlenschläger, J. Determination of zinc and copper in fish samples 639 collected from Northeast Atlantic by DPSAV. Food Chem. 2004, 87, 343-347.

640 (33) Cronin, M.; Davies, I.M.; Newton, A.; Pirie, J.M.; Topping, G.; Swan, S.C. Trace 641 metal concentrations in deep sea fish from the North Atlantic. Mar. Environ. Res. $642 \quad 1998,45,225-238$.

643 (34) Carvalho, M.L.; Santiago, S.; Nunes, M.L. Assessment of the essential element and 644 heavy metal content of edible fish muscle. Anal. Bioanal. Chem. 2005, 382, 426645432.

646 (35) Zauke, G.-P.; Savinov, V.M.; Ritterhoff, J.; Savinova, T. Heavy metals in fish from 647 the Barents Sea (summer 1994). Sci. Total Environ. 1999, 227, 161-173.

648 (36) Fernandes, D.; Bebianno, M.J.; Porte, C. Hepatic levels of metal and 649 metallothioneins in two commercial fish species of the Northern Iberian shelf. Sci. $650 \quad$ Total Environ. 2008, 391, 159-167.

651 (37) Cabañero, A.I.; Madrid Y.; Cámara C. Mercury-Selenium species ratio in 652 representative fish samples and their bioaccessibility by an in vitro digestion 653 method. Biol. Trace Elem. Res. 2007, 119, 195-211. 
654 (38) Roméo, M.; Siau, Y.; Sidoumou, Z.; Gnassia-Barelli, M. Heavy metal distribution in different fish species from the Mauritania coast. Sci. Total Environ. 1999, 232, 169-175.

657 (39) Mormede, S.; Davies, I.M. Horizontal and vertical distribution of organic contaminants in deep-sea fish species. Chemosphere 2003, 50, 563-574.

(40) Storelli, M.M.; Barone, G.; Marcotrigiano, G.O. Residues of polychlorinated 660 biphenyls in edible fish of the Adriatic Sea: Assessment of human exposure. J. Food Sci. 2007, 72, C183-C187.

663

(41) Mezzetta, S.; Cirlini, M.; Ceron, P.; Tecleanu, A.; Caligiani, A.; Palla, G.; Sansebastiano, G.E. Concentration of DL-PCBs in fish from market of Parma city

665 (north Italy): Estimated human intake. Chemosphere 2011, 82, 1293-1300.

(42) Storelli, M.M.; Barone, G.; Perrone, V.G.; Giacominelli-Stuffler, R. 666 Polychlorinated biphenyls (PCBs), dioxins and furans (PCDD/Fs): Occurrence in fishery products and dietary intake. Food Chem. 2011, 127, 1648-1652.

(43) Shaw, S.D.; Berger, M.L.; Brenner, D.; Kannan, K.; Lohmann, N.; Päpke, O. Bioaccumulation of polybrominated diphenyl ethers and hexabromocyclododecane in the northwest Atlantic marine food web. Sci. Total Environ. 2009, 407, 3323-

(44) Bordajandi, L.R.; Martín I.; Abad, E.; Rivera, J.; González, M.J. Organochlorine compounds (PCBs, PCDDs and PCDFs) in seafish and seafood from the Spanish Atlantic Southwest Coast. Chemosphere 2006, 64, 1450-1457.

(45) Naso, B.; Perrone, D.; Ferrante, M.C.;Bilancione, M.; Lucisano, A. Persistent organic pollutants in edible marine species from the Gulf of Naples, Southern Italy. Sci. Total Environ. 2005, 343, 83-95. Mediterranean deep-sea fish Mora moro. Deep-Sea Res. I 2001, 48, 495-513. 
680

681

682

683

684

685

686

687

688

689

690

691

692

693

694

695

696

697

698

699

700

701

702

703

704

705

(47) Storelli, M.M.; Barone, G.; Giacominelli-Stuffler, R.; Marcotrigiano, G.O. Levels and profiles of DDTs and PCBs in a gadiform fish (Phycis blennoides) from Mediterranean Sea. Baseline / Mar. Pollut. Bull. 2008, 56, 1353-1376.

(48) Gómara, B.; Bordajandi, L. R.; Fernández, M.A.; Herrero, L.; Abad, E.; Abalos, M.; Rivera, J.; González, M.J. Levels and trends of polychlorinated dibenzo-pdioxins/furans (PCDD/Fs) and dioxin-like polychlorinated biphenyls (PCBs) in Spanish commercial fish and shellfish products, 1995-2003. J. Agric. Food Chem. 2005, 53, 8406-8413.

(49) Corsolini, S.; Ademollo, N.; Romeo, T.; Greco, S.; Focardi, S. Persistent organic pollutants in edible fish: a human and environmental health problem. Microchem. $J$. 2005, 79, 115-123.

(50) Castro-González, M.I.; Méndez-Armenta, M. Heavy metals: Implications associated to fish consumption. Environ. Toxicol. Pharm. 2008, 26, 263-271.

(51) Dobrzanski, Z.; Bykowski, P.; Iwaniuk, Z.; Usydus, Z.; Górecka, H.; Trziszka, T. Evaluation of the chemical composition of fish oil: a by-product from fish processing plants in the southern Baltic Sea. Bull. Sea Fish. Inst. 2002, 155, 39-46.

(52) Jacobs, M.N.; Covaci, A.; Schepens, P. Investigation of selected persistent organic pollutants in farmed Atlantic Salmon (Salmo salar), salmon aquaculture feed, and fish oil components of the feed. Environ. Sci. Technol. 2002, 36, 2797-2805.

(53) Ortiz, X.; Guerra, P.; Díaz-Ferrero, J.; Eljarrat, E.; Barceló, D. Diastereoisomerand enantiomer-specific determination of hexabromocyclododecane in fish oil for food and feed. Chemosphere 2011a, 82, 739-744.

(54) Carbonelle, S.; Eppe, G.; Hellebosch, L.; De Meulenaer, B.; Vila Ayala, J.; De Greyt, W.; Verhé, R.; De Pauw, E.; Goeyens, L. Removal of dioxins and PCBs in fish oils: comparison of CALUX and GC-HRMA results. Organohalogen Compd. 2005, 67, 31-34. 
(55) Maes, J.; De Meulenaer, B.; Van Heerswynghels, P.; De Greyt, W.; Eppe, G.; De

707 Pauw E.; Huyghebaert A. Removal of dioxins and PCB from fish oil by activated 708 carbon and its Influence on the nutritional quality of the oil. J. Am. Oil Chem. Soc. $709 \quad 2005,82,593-597$.

710 (56) Hilbert, G.; Lillemark, L.; Balchen, S.; Hojskov, C.S. Reduction of organochlorine 711 contaminants from fish oil during refining. Chemosphere 1989, 37, 1241-1252.

712 (57) Eppe, G.; Carbonnelle, S.; Hellebosch, L.; De Meulenaer, B.; Vila Ayala, J.; De 713 Greyt, W.; Verhé, R.; Goeyens, L.; Focant, J.; De Pauw, E. Removal of PCDD/Fs 714 and DL-PCBs from fish oil by activated carbon: Compliance with European 715 Legislation. Organohalogen Compd. 2005, 67, 1412-1416.

716 (58) Oterhals A.; Solvanga, M.; Nortvedt, R.; Berntssen, M.H.G. Optimization of 717 activated carbon-based decontamination of fish oil by response surface 718 methodology. Eur. J. Lipid Sci. Technol. 2007, 109, 691-705.

719 (59) Usydus, Z.; Szlinder-Richert, J.; Polak-Juszczak, L.; Malesa-Ciewierz, M.; 720 Dobrzanski, Z. Study on the raw fish oil purification from PCDD/F and dl-PCB721 industrial tests. Chemosphere 2009, 74, 1495-1501.

722 (60) Usydus, Z.; Dobrzanski, Z.; Polak-Juszczak, L. Study on the purification of raw 723 fish oil. Chem. Agric. 2007, 8, 280-286.

724 (61) Ortiz, X.; Carabellido, L.; Martí, M.; Martí, R.; Tomás, X.; Díaz-Ferrero, J. 725 Elimination of persistent organic pollutants from fish oil with solid adsorbents. 726 Chemosphere 2011b, 82, 1301-1307.

727 (62) Kawashima, A.; Iwakiri, R.; Honda, K. Experimental study on the removal of 728 dioxins and coplanar polychlorinated biphenyls (PCBs) from fish oil. J. Agric. Food Chem. 2006, 54, 10294-10299.

730 (63) Krukonis, V.J. Supercritical fluid processing of fish oils: extraction of 731 polychlorinated biphenyls. J. Am. Oil Chem. Soc. 1989, 66, 818-821. 
(64) Jakobsson, M.; Sivik, B.; Bergqvist, P.A.; Strandberg, B.; Rappe, C. Countercurrent extraction of dioxins from cod liver oil by supercritical carbon dioxide. The J. Supercrit. Fluid 1994, 7, 197-200.

(65) Oterhals, A.; Kvamme, B.; Berntssen, M.H.G. Modeling of a short-path distillation process to remove persistent organic pollutants in fish oil based on process parameters and quantitative structure properties relationships. Chemosphere 2010, 80, 83-92.

(66) Cornelissen, G.; Gustafsson, O.; Bucheli, T.D.; Jonker, M.T.O.; Koelmans, A.A.; van Noort, P.C.M. Extensive sorption of organic compounds to black carbon, coal, and kerogen in sediments and soils: mechanisms and consequences for distribution, bioaccumulation and biodegradation. Environ. Sci. Technol. 2005, 39, 6881-6895.

(67) Oterhals, A.; Berntssen, M.H.G. Effects of refining and removal of persistent organic pollutants by short-path distillation on nutritional quality and oxidative stability of fish oil. J. Agric. Food Chem. 2010, 58, 12250-12259.

(68) Carbonnelle, S.; Eppe, G.; Hellebosch, L.; De Meulenaer, B.; Vila Ayala, J.; De Greyt, W.; Verhé, R.; De Pauw, E.; Goeyens, L. Removal of PCDD/Fs and DLPCBs from fish oils by volatilisation procedures. Organohalogen Compd. 2006, 68, 620-623.

(69) Baron, C.P.; Borresen, T.; Jacobsen, C. UV treatment of fishmeal: a method to remove dioxins?. J. Agric. Food Chem. 2005, 53, 7091-7097.

(70) Baron, C.P.; Borresen, T.; Jacobsen, C. Comparison of methods to reduce dioxin and polychlorinated biphenyls contents in fishmeal: extraction and enzymatic treatments. J. Agric. Food Chem. 2007, 55, 1620-1626.

(71) Oterhals, A.; Nygard, E. Reduction of persistent organic pollutants in fishmeal: A feasibility study. J. Agric. Food Chem. 2008, 56, 2012-2020. 
757 (72) Tavakoli, O.; Yoshida, H. Effective recovery of harmful metal ions from squid 758 wastes using subcritical and supercritical water treatments. Environ. Sci. Technol. 2005, 39, 2357-2363.

760 (73) Ghimire, K.N.; Kai, H.; Inoue, K.; Ohto, K.; Kawakita, H.; Harada, H.; Morita, M. 761 Heavy metal removal from contaminated scallop waste for feed and fertilizer 762 application. Bioresource Technol. 2008, 99, 2436-2441.

763 
Table S1. Presence of Different Pollutants in Discarded Species of Spanish and Portuguese Métiers

\begin{tabular}{|c|c|}
\hline Specie & Pollutant profile \\
\hline Actinauge richardi & No data available \\
\hline Alosa alosa & - \\
\hline Alosa fallax & - \\
\hline Alepocephalus rostratus & No data available \\
\hline Aphanopus carbo & Heavy metals (Al, Cd, Cr, Co, Cu, Fe, Pb, Li, Mn, $\mathrm{Hg}, \mathrm{Ni}, \mathrm{Se}, \mathrm{V}$ and $\mathrm{Zn}$ ) \\
\hline Argentina silus & - \\
\hline Argentina sphyraena & - \\
\hline Argobuccinum olearium & No data available \\
\hline Arnoglossus imperialis & - \\
\hline Arnoglossus laterna & - \\
\hline Aspitrigla cuculus & - \\
\hline Asteroidea & No data available \\
\hline Beryx decadactylus & - \\
\hline Boops boops & - \\
\hline Brama brama & - \\
\hline Brosme brosme & $\begin{array}{l}\text { PCBs, } \alpha-\mathrm{HCH}, \mathrm{DDE}, \mathrm{DDT}, \gamma-\mathrm{HCH}, \mathrm{HCB} \text {, octachlorostyrene, pentachlorobenzene, DDD and heavy metals } \\
(\mathrm{Cd}, \mathrm{Cu}, \mathrm{Pb}, \mathrm{Hg} \text { and } \mathrm{Zn})\end{array}$ \\
\hline Buccinum spp. & No data available \\
\hline Caelorinchus caelorhincus & - \\
\hline Callionymus lyra & - \\
\hline Callionymus reticulatus & - \\
\hline Cancer bellianus & No data available \\
\hline Cancer pagurus & - \\
\hline Capros aper & - \\
\hline Cassidaria tyrrhena & No data available \\
\hline Centrolophus niger & No data available \\
\hline Centrophorus granulosus & No data available \\
\hline Centrophorus squamosus & No data available \\
\hline Centroscymnus coelolepis & No data available \\
\hline Centrostephanus longispinus & No data available \\
\hline Cepola macrophthalma & No data available \\
\hline Charonia lampas & No data available \\
\hline Chelidonichthys cuculus & - \\
\hline Chelidonichthys gurnardus & No data available \\
\hline Chelidonichthys lucerna & No data available \\
\hline Chimaera monstrosa & $\begin{array}{l}\text { PCBs, } \alpha-\mathrm{HCH}, \mathrm{DDE}, \mathrm{DDT}, \gamma-\mathrm{HCH}, \mathrm{HCB} \text {, octachlorostyrene, pentachlorobenzene, DDD and heavy metals } \\
(\mathrm{Cd}, \mathrm{Cu}, \mathrm{Pb}, \mathrm{Hg} \text { and } \mathrm{Zn})\end{array}$ \\
\hline Caelorinchus caelorhincus & - \\
\hline Conger conger & - \\
\hline Coryphaenoides rupestris & Heavy metals (Al, Cd, Cr, Co, Cu, Fe, Pb, Li, Mn, Hg, Ni, Se, V and $\mathrm{Zn}$ ) \\
\hline Crinoidea & No data available \\
\hline Crustacea & - \\
\hline Dalatias licha & No data available \\
\hline Dardanus arrosor & No data available \\
\hline Deania calcea & No data available \\
\hline Dipturus batis & - \\
\hline Echinoidea & No data available \\
\hline Echinodermata & - \\
\hline Echinus acutus & No data available \\
\hline Eledone cirrhosa & - \\
\hline Etmopterus spinax & - \\
\hline Eutrigla gurnardus & - \\
\hline Gadiculus argenteus & - \\
\hline Gadus morhua & $\begin{array}{l}\text { Dioxins, furans, benzenes, bromocyclododecane, naphthalenes, PCBs, PAHs, alpha-endosulfan, } \alpha-\mathrm{HCH}, \alpha- \\
\text { HBCD, } \beta \text {-endosulfan, } \beta \text {-HCH, } \beta \text {-HBCD, dibenzothiophenes, cesium-134, cesium-137, cis-chlordane, cis- } \\
\text { nonachlor, DDE, DDT, PBDEs, dibutyltin, dieldrin, endrin, } \gamma \text {-HCH, } \gamma-\mathrm{HBCD} \text {, heptachlor, heptachlor epoxide, } \\
\mathrm{HCB} \text {, hexachlorobutadiene, methoxychlor, mirex, monobutyltin, monophenyltin, PBTs, oxychlordane, } \\
\text { toxaphene, pentachlorothioanisole, perfluorodecanoic acid, perfluoroheptanoic acid, perfluorohexanesulfonic } \\
\text { acid, perfluorohexanoic acid, perfluorononanoic acid, perfluorooctanoic acid, perfluorooctanyl sulphonic acid, } \\
\text { perfluorooctylsulfonate acid amide, perylene, radium-226, radium-228, N, P, DDD, tetrabromobiphenol, } \\
\text { trans-chlordane, trans-nonachlor, tributyltin, triphenyltin and heavy metals (As, Cd, Cr, Co, Cu, Fe, Pb, Mg, } \\
\mathrm{Mn}, \mathrm{Mo}, \mathrm{Hg}, \mathrm{Na}, \mathrm{Ni}, \mathrm{K}, \mathrm{Se}, \mathrm{Sn} \text { and } \mathrm{Zn} \text { ) }\end{array}$ \\
\hline Gaidropsarus guttatus & No data available \\
\hline Galeorhinus galeus & - \\
\hline Galeus melastomus & - \\
\hline Gastropoda & - \\
\hline Geryon longipes & No data available \\
\hline Glyptocephalus cynoglossus & $\begin{array}{l}\text { PCBs, } \alpha-\mathrm{HCH}, \mathrm{DDE}, \gamma-\mathrm{HCH}, \mathrm{HCB} \text {, octachlorostyrene, pentachlorobenzene, DDD and heavy metals }(\mathrm{Cd}, \mathrm{Cu} \text {, } \\
\mathrm{Pb}, \mathrm{Hg} \text { and } \mathrm{Zn})\end{array}$ \\
\hline Gobiidae & - \\
\hline Halargyreus johnsonii & No data available \\
\hline Helicolenus dactylopterus & - \\
\hline
\end{tabular}


Hexanchus griseus

Hippoglossoides platessoides

Holothuria spp.

Holothurioidea

Hoplostethus atlanticus

Hoplostethus mediterraneus

Illex coindetii

Lepidion eques

Lepidopus caudatus

Lepidorhombus boscii

Lepidorhombus spp.

Lepidorhombus whiffiagonis

Leucoraja circularis

Leucoraja naevus

Liocarcinus depurator

Loligo vulgaris

Lophius budegassa

Lophius piscatorius

Lophius spp.

Macropipus tuberculatus

Macropodia tenuirrostris

longipes

Macroramphosus scolopax

Malacocephalus laevis

Melanogrammus aeglefinus

Merlangius merlangus

Merluccius merluccius

Microchirus variegatus

Micromesistius poutassou

Microstomus kitt

Mola mola

Mollusca

Molpadiidae

Molva dypterygia

Molva molva

Mora moro

Munida spp.

Mustelus asterias

Nephrops norvegicus

Nettastoma melanurum

Nezumia aequalis

Nezumia sclerorhynchus

Octopodidae

Ommastrephidae

Opisthoteuthis agassici

Ophiothrix fragilis

Ophiura spp.

Pagellus acarne

Pagellus bogaraveo

Pagurus alatus

Pagurus spp.

Parapenaeus longirostris

Paromola cuvieri

Phycis blennoides

Phycis spp.

Pisces

Plesionika spp.

Pleuronectes platessa

Pollachius virens

Polybius henslowi

Polychaeta

Raja asterias

Raja brachyuran

Raja clavata
PCBs, $\alpha-\mathrm{HCH}, \beta-\mathrm{HCH}$, cis-chlordane, DDE, DDT, $\gamma-\mathrm{HCH}$, HCB, oxychlordane, DDD, trans-chlordane, transnonachlor and heavy metals (As, $\mathrm{Cd}, \mathrm{Cr}, \mathrm{Cu}, \mathrm{Pb}, \mathrm{Hg}, \mathrm{Ni}$, Se and $\mathrm{Zn}$ )

No data available

No data available

Heavy metals (Al, Cd, Cr, Co, Cu, Fe, Pb, Li, Mn, Hg, Ni, Se, V and Zn)

No data available

$-$

No data available

PCBs, $\alpha-\mathrm{HCH}$, cis-chlordane, DDE, DDT, dieldrin, $\gamma-\mathrm{HCH}, \mathrm{HCB}$, octachlorostyrene, pentachlorobenzene, $\mathrm{DDD}$, trans-chlordane, trans-nonachlor and heavy metals (As, $\mathrm{Cd}, \mathrm{Cr}, \mathrm{Co}, \mathrm{Cu}, \mathrm{Pb}, \mathrm{Hg}, \mathrm{Ni}, \mathrm{Ag}, \mathrm{Sn}$ and $\mathrm{Zn}$ ) $-$

No data available

PCBs, $\alpha-\mathrm{HCH}$, cis-chlordane, DDE, DDT, dieldrin, $\gamma-\mathrm{HCH}, \mathrm{HCB}, \mathrm{DDD}$, trans-chlordane, trans-nonachlor and heavy metals (Al, Cd, Cr, Co, Cu, Fe, Pb, Li, Mn, Hg, Ni, Se, V and Zn)

No data available

PCBs, PAHs, $\alpha-\mathrm{HCH}$, dibenzothiophenes, naphthalenes, cis-chlordane, DDE, DDT, dieldrin, $\gamma-\mathrm{HCH}, \mathrm{HCB}$, oxychlordane, perylene, DDD, trans-chlordane, trans-nonachlor and heavy metals ( $\mathrm{Cd}, \mathrm{Cu}, \mathrm{Pb}, \mathrm{Hg}$ and $\mathrm{Zn}$ ) PCBs, PAHs, $\alpha-\mathrm{HCH}$, dibenzothiophenes, naphthalenes, cis-chlordane, DDE, DDT, $\gamma-\mathrm{HCH}$, HCB, perylene, $\mathrm{DDD}$, trans-chlordane, trans-nonachlor and heavy metals ( $\mathrm{As}, \mathrm{Cd}, \mathrm{Cu}, \mathrm{Pb}, \mathrm{Hg}$ and $\mathrm{Zn}$ )

$\mathrm{PCBs}, \alpha-\mathrm{HCH}, \beta-\mathrm{HCH}$, cis-chlordane, DDE, DDT, dieldrin, $\gamma-\mathrm{HCH}, \mathrm{HCB}, \mathrm{DDD}$, trans-chlordane, transnonachlor and heavy metals $(\mathrm{Cd}, \mathrm{Cr}, \mathrm{Cu}, \mathrm{Pb}, \mathrm{Hg}$ and $\mathrm{Zn})$

Heavy metals (Cd, Co, Cu, Pb, Li, Hg, Ni, Se, V and $\mathrm{Zn}$ )

$\alpha-\mathrm{HCH}$, PCBs, dibenzothiophenes, naphthalenes, chrysene, cis-chlordane, DDE, DDT, dieldrin, $\gamma-\mathrm{HCH}$ chlorobenzenes, octachlorostyrene, perylene, DDD, trans-chlordane, trans-nonachlor and heavy metals $(\mathrm{Cd}$, $\mathrm{Cu}, \mathrm{Pb}, \mathrm{Hg}$ and $\mathrm{Zn}$ )

No data available

No data available

Heavy metals (Al, Cd, Cr, Co, Cu, Fe, Pb, Mn, Hg, Ni, Se and $\mathrm{Zn}$ )

PCBs, $\alpha-\mathrm{HCH}, \gamma-\mathrm{HCH}$, DDE, DDT, benzenes, octachlorostyrene, DDD and heavy metals $(\mathrm{Cd}, \mathrm{Cu}, \mathrm{Pb}, \mathrm{Hg}$ and $\mathrm{Zn})$

No data available

Naphthalenes, PCBs, PAHs, dibenzothiophenes, naphthalene, perylene and heavy metals $(\mathrm{Cd}, \mathrm{Cu}, \mathrm{Pb}, \mathrm{Hg}$ and $\mathrm{Zn}$ )

No data available

No data available

No data available

$-$

No data available

No data available

No data available

No data available

No data available

No data available

No data available

No data available

PAHs, naphthalenes, PCBs, $\alpha-\mathrm{HCH}$, cis-chlordane, DDE, DDT, $\delta-\mathrm{HCH}, \gamma-\mathrm{HCH}$, dieldrin, benzenes, perylenes, DDD, trans-chlordane, trans-nonachlor and heavy metals ( $\mathrm{As}, \mathrm{Ba}, \mathrm{Cd}, \mathrm{Cr}, \mathrm{Co}, \mathrm{Cu}, \mathrm{Pb}, \mathrm{Mn}, \mathrm{Hg}, \mathrm{Ni}$, $\mathrm{Se}, \mathrm{Ag}, \mathrm{Sr}, \mathrm{Sn}, \mathrm{V}$ and $\mathrm{Zn}$ )

DDE, DDT, $\gamma$-HCH, HCB, PCBs and heavy metals (Cd, $\mathrm{Cu}, \mathrm{Pb}, \mathrm{Hg}$ and $\mathrm{Zn})$

No data available

No data available

No data available

$\mathrm{Hg}$ 


\begin{tabular}{|c|c|}
\hline Raja montagui & $\mathrm{Hg}$ \\
\hline Rajidae & No data available \\
\hline Rhizopoda & No data available \\
\hline Rossia macrosoma & - \\
\hline Sacoglossa & No data available \\
\hline Sardina pilchardus & PCBs and heavy metals $(\mathrm{Cd}, \mathrm{Cu}, \mathrm{Pb}, \mathrm{Hg}$ and $\mathrm{Zn})$ \\
\hline Scaphander lignarius & No data available \\
\hline Scomber colias & No data available \\
\hline Scomber scombrus & $\begin{array}{l}\mathrm{PCBs}, \alpha-\mathrm{HCH} \text {, cris-chlordane, DDE, DDT, dieldrin, } \gamma-\mathrm{HCH}, \mathrm{HCB}, \mathrm{DDD} \text {, trans-chlordane, trans-nonachlor } \\
\text { and heavy metals }(\mathrm{Cd}, \mathrm{Cr}, \mathrm{Cu}, \mathrm{Pb}, \mathrm{Hg} \text { and } \mathrm{Zn})\end{array}$ \\
\hline Scyliorhinus canicula & $\mathrm{Hg}$ \\
\hline Scymnodon ringens & No data available \\
\hline Scyphozoa & - \\
\hline Sepia officinalis & - \\
\hline Sepia orbignyana & - \\
\hline Sepia spp. & - \\
\hline Sepiola spp. & - \\
\hline Squalus acanthias & - \\
\hline Sphoeroides pachygaster & No data available \\
\hline Stichopus spp. & No data available \\
\hline Stichopus tremulus & No data available \\
\hline Tealia spp. & No data available \\
\hline Todarodes sagittatus & No data available \\
\hline Todaropsis eblanae & - \\
\hline Torpedo marmorata & - \\
\hline Trachurus mediterraneus & No data available \\
\hline Trachurus picturatus & No data available \\
\hline Trachurus spp. & No data available \\
\hline Trachurus trachurus & - \\
\hline Trachyrincus scabrus & No data available \\
\hline Trigla lyra & - \\
\hline Trigla spp. & No data available \\
\hline Triglidae & No data available \\
\hline Trisopterus luscus & - \\
\hline Trisopterus minutus & - \\
\hline Zeus faber & - \\
\hline
\end{tabular}


Table 1. Metal Levels in Atlantic Fish Species

\begin{tabular}{|c|c|c|c|c|}
\hline \multicolumn{2}{|c|}{$\begin{array}{l}\text { Specie, origin and tissue (muscle when not } \\
\text { specified) }\end{array}$} & Pollutant & Concentration (mg/kg ww) & Reference \\
\hline \multicolumn{5}{|l|}{ Aphanopus carbo } \\
\hline \multicolumn{5}{|l|}{ (black scabbardfish) } \\
\hline \multirow[t]{10}{*}{ West Scotland } & muscle & As & $<0.002-26.49$ & (30) \\
\hline & & $\mathrm{Cd}$ & $<0.002-0.017$ & \\
\hline & & $\mathrm{Cu}$ & $0.07-0.27$ & \\
\hline & & $\mathrm{Pb}$ & $0.002-0.052$ & \\
\hline & & $\mathrm{Zn}$ & $2.12-3.90$ & \\
\hline & liver & As & $<0.05-35.79$ & \\
\hline & & $\mathrm{Cd}$ & $2.06-18.24$ & \\
\hline & & $\mathrm{Cu}$ & $<1.00-39.05$ & \\
\hline & & $\mathrm{Pb}$ & $<0.05-0.471$ & \\
\hline & & $\mathrm{Zn}$ & $29.42-108.70$ & \\
\hline \multirow[t]{7}{*}{ Madeira and Azores } & muscle & $\mathrm{Hg}$ & $0.19-1.43$ & (31) \\
\hline & & $\mathrm{Cd}$ & 0.01-0.09 & \\
\hline & & $\mathrm{Pb}$ & nd- 0.10 & \\
\hline & liver & $\mathrm{Hg}$ & $0.28-1.19$ & \\
\hline & skin & $\mathrm{Hg}$ & $0.04-1.44$ & \\
\hline & & $\mathrm{Cd}$ & $0.02-0.11$ & \\
\hline & & $\mathrm{Pb}$ & nd- 0.10 & \\
\hline \multirow{2}{*}{\multicolumn{5}{|c|}{$\begin{array}{l}\text { Brosme brosme } \\
\text { (tusk or cusk) }\end{array}$}} \\
\hline & & & & \\
\hline \multirow[t]{2}{*}{ Northeast Atlantic } & & $\mathrm{Zn}$ & $3.0-3.5$ & (32) \\
\hline & & $\mathrm{Cu}$ & $0.13-0.18$ & \\
\hline \multirow{2}{*}{\multicolumn{5}{|c|}{$\begin{array}{l}\text { Chelidonichthys gurnardus } \\
\text { (grey gurnard) }\end{array}$}} \\
\hline & & & & \\
\hline \multirow[t]{2}{*}{ Northeast Atlantic } & & $\mathrm{Zn}$ & $3.0-4.2$ & (32) \\
\hline & & $\mathrm{Cu}$ & $0.23-0.39$ & \\
\hline \multicolumn{5}{|l|}{ Conger conger } \\
\hline \multicolumn{5}{|l|}{ (European conger) } \\
\hline Croatia & & $\mathrm{Hg}$ & 0.864 & (7) \\
\hline \multicolumn{5}{|c|}{ Coryphaneoides rupestris } \\
\hline \multicolumn{5}{|l|}{ (roundnose grenadier) } \\
\hline \multirow{5}{*}{\multicolumn{2}{|c|}{ West Scotland }} & $\mathrm{Cd}$ & ND-0.01 & (33) \\
\hline & & $\mathrm{Cu}$ & $0.03-0.54$ & \\
\hline & & $\mathrm{Pb}$ & ND-0.06 & \\
\hline & & $\mathrm{Hg}$ & $0.02-0.28$ & \\
\hline & & $\mathrm{Zn}$ & $1.7-2.9$ & \\
\hline \multicolumn{5}{|c|}{ Helicolenus dactylopterus } \\
\hline \multicolumn{5}{|l|}{ (blackbelly rosefish) } \\
\hline \multirow{2}{*}{\multicolumn{2}{|c|}{ Portuguese coast }} & $\mathrm{Cr}$ & $0.23-0.28$ & ${ }^{1}(34)$ \\
\hline & & $\mathrm{Ni}$ & $0.038-0.065$ & \\
\hline
\end{tabular}




\begin{tabular}{|c|c|c|c|}
\hline $\begin{array}{l}\text { Specie, origin and tissue (muscle when not } \\
\text { specified) }\end{array}$ & Pollutant & Concentration (mg $/ \mathrm{kg} \mathrm{ww})$ & Reference \\
\hline & $\mathrm{Hg}$ & $0.44-1.35$ & \\
\hline & $\mathrm{Pb}$ & ND & \\
\hline & $\mathrm{Cd}$ & $0.025-0.013$ & \\
\hline \multicolumn{4}{|l|}{ Hippoglossoides platessoides } \\
\hline \multicolumn{4}{|l|}{ (American plaice) } \\
\hline \multirow[t]{8}{*}{ Barents Sea } & $\mathrm{Cd}$ & 0.4 & ${ }^{1}(35)$ \\
\hline & $\mathrm{Hg}$ & 0.018 & \\
\hline & $\mathrm{Cu}$ & 8.0 & \\
\hline & $\mathrm{Zn}$ & 29.75 & \\
\hline & $\mathrm{Hg}$ & 0.093 & \\
\hline & $\mathrm{Cu}$ & $<0.43$ & \\
\hline & Zn & 4.75 & \\
\hline \multirow{2}{*}{\multicolumn{4}{|c|}{$\begin{array}{l}\text { Hoplostethus atlanticus } \\
\text { (orange roughy) }\end{array}$}} \\
\hline & & & \\
\hline \multirow[t]{5}{*}{ West Scotland } & Cd & ND-0.01 & (33) \\
\hline & $\mathrm{Cu}$ & $0.04-0.19$ & \\
\hline & $\mathrm{Pb}$ & ND-0.66 & \\
\hline & $\mathrm{Hg}$ & $0.11-0.86$ & \\
\hline & Zn & $2.0-3.4$ & \\
\hline \multicolumn{4}{|l|}{ Lepidorhombus boscii } \\
\hline \multicolumn{4}{|l|}{ (four-spot megrim) } \\
\hline \multirow[t]{7}{*}{ Northern Iberian shelf-liver } & $\mathrm{Cu}$ & $2.45-6.93$ & ${ }^{1}(36)$ \\
\hline & Zn & $19.5-40.75$ & \\
\hline & $\mathrm{Cr}$ & $0.25-0.72$ & \\
\hline & $\mathrm{Fe}$ & $25.25-55.5$ & \\
\hline & Cd & $0.025-0.34$ & \\
\hline & $\mathrm{Pb}$ & $0.0005-0.0028$ & \\
\hline & $\mathrm{Hg}$ & $0.0028-0.11$ & \\
\hline \multirow{2}{*}{\multicolumn{4}{|c|}{$\begin{array}{l}\text { Lepidorhombus whiffiagonis } \\
\text { (megrim) }\end{array}$}} \\
\hline & & & \\
\hline \multirow[t]{2}{*}{ Northeast Atlantic } & Zn & $2.1-2.9$ & (32) \\
\hline & $\mathrm{Cu}$ & $0.13-0.47$ & \\
\hline \multicolumn{4}{|l|}{ Loligo vulgaris } \\
\hline \multicolumn{4}{|l|}{ (European squid) } \\
\hline \multirow[t]{4}{*}{ Catalonian markets } & As & $1.41-4.74$ & (6) \\
\hline & $\mathrm{Cd}$ & $0.05-0.15$ & \\
\hline & $\mathrm{Hg}$ & $0.02-0.03$ & \\
\hline & $\mathrm{Pb}$ & $0.01-0.01$ & \\
\hline France & $\mathrm{Hg}$ & 0.047 & (7) \\
\hline \multicolumn{4}{|l|}{ Lophius piscatorus } \\
\hline \multicolumn{4}{|l|}{ (monkfish) } \\
\hline \multirow[t]{2}{*}{ West Scotland } & As & $2.70-21.47$ & (30) \\
\hline & $\mathrm{Cd}$ & $<0.002-0.041$ & \\
\hline
\end{tabular}




\begin{tabular}{|c|c|c|c|}
\hline $\begin{array}{l}\text { Specie, origin and tissue (muscle when not } \\
\text { specified) }\end{array}$ & \multirow{2}{*}{$\begin{array}{l}\text { Pollutant } \\
\mathrm{Cu}\end{array}$} & \multirow{2}{*}{$\begin{array}{l}\text { Concentration (mg/kg ww) } \\
0.06-0.22\end{array}$} & \multirow[t]{2}{*}{ Reference } \\
\hline & & & \\
\hline & $\mathrm{Pb}$ & $<0.002-0.041$ & \\
\hline liver & As & $1.44-14.33$ & \\
\hline & $\mathrm{Cd}$ & $<0.05-1.4$ & \\
\hline & $\mathrm{Cu}$ & $1.45-36.44$ & \\
\hline & $\mathrm{Pb}$ & $<0.05-0.074$ & \\
\hline \multirow[t]{2}{*}{ Northeast Atlantic } & $\mathrm{Zn}$ & $2.6-3.3$ & (32) \\
\hline & $\mathrm{Cu}$ & $0.10-0.29$ & \\
\hline \multirow[t]{5}{*}{ Portuguese coast } & $\mathrm{Cr}$ & $0.0075-0.53$ & (34) \\
\hline & $\mathrm{Ni}$ & $0.02-0.053$ & \\
\hline & $\mathrm{Hg}$ & $0.118-0.63$ & \\
\hline & $\mathrm{Pb}$ & $<0.0075$ & \\
\hline & $\mathrm{Cd}$ & $0.0025-0.0075$ & \\
\hline Croatia & $\mathrm{Hg}$ & $0.071-0.678$ & (7) \\
\hline \multicolumn{4}{|l|}{$\begin{array}{l}\text { Melanogrammus aeglefinus } \\
\text { (haddock) }\end{array}$} \\
\hline \multirow[t]{7}{*}{ Barents Sea } & $\mathrm{Cd}$ & 0.35 & ${ }^{1}(35)$ \\
\hline & $\mathrm{Hg}$ & 0.013 & \\
\hline & $\mathrm{Cu}$ & 6.75 & \\
\hline & $\mathrm{Zn}$ & 14 & \\
\hline & $\mathrm{Hg}$ & 0.083 & \\
\hline & $\mathrm{Cu}$ & $<0.43$ & \\
\hline & $\mathrm{Zn}$ & 3.75 & \\
\hline \multirow[t]{2}{*}{ Northeast Atlantic } & $\mathrm{Zn}$ & $2.2-4.0$ & (32) \\
\hline & $\mathrm{Cu}$ & $0.13-0.34$ & \\
\hline \multicolumn{4}{|l|}{$\begin{array}{l}\text { Merluccius merluccius } \\
\text { (hake) }\end{array}$} \\
\hline \multirow[t]{8}{*}{ West Scotland } & As & $0.08-3.30$ & (30) \\
\hline & $\mathrm{Cd}$ & $<0.002-0.062$ & \\
\hline & $\mathrm{Cu}$ & $0.16-0.54$ & \\
\hline & $\mathrm{Pb}$ & $<0.002-0.047$ & \\
\hline & As & $<0.05-7.59$ & \\
\hline & $\mathrm{Cd}$ & $<0.05-1.43$ & \\
\hline & $\mathrm{Cu}$ & $<1.00-17.89$ & \\
\hline & $\mathrm{Pb}$ & $<0.05-0.159$ & \\
\hline \multirow[t]{2}{*}{ Northeast Atlantic } & $\mathrm{Zn}$ & $3.2-3.3$ & (32) \\
\hline & $\mathrm{Cu}$ & $0.20-0.61$ & \\
\hline \multirow[t]{4}{*}{ Catalonian markets } & As & $3.22-4.55$ & (6) \\
\hline & $\mathrm{Cd}$ & $0.005-0.01$ & \\
\hline & $\mathrm{Hg}$ & $0.12-0.29$ & \\
\hline & $\mathrm{Pb}$ & $0.01-0.13$ & \\
\hline Croatia & $\mathrm{Hg}$ & 0.052 & (7) \\
\hline
\end{tabular}




\begin{tabular}{|c|c|c|c|}
\hline $\begin{array}{l}\text { Specie, origin and tissue (muscle when not } \\
\text { specified) }\end{array}$ & Pollutant & Concentration (mg/kg ww) & Reference \\
\hline \multicolumn{4}{|l|}{ (blue whiting) } \\
\hline \multirow[t]{8}{*}{ West Scotland } & As & $0.37-6.10$ & (30) \\
\hline & $\mathrm{Cd}$ & $<0.002-1.178$ & \\
\hline & $\mathrm{Cu}$ & $0.19-0.45$ & \\
\hline & $\mathrm{Pb}$ & $0.005-0.030$ & \\
\hline & As & $1.52-13.74$ & \\
\hline & $\mathrm{Cd}$ & $0.06-1.29$ & \\
\hline & $\mathrm{Cu}$ & $2.56-10.18$ & \\
\hline & $\mathrm{Pb}$ & $<0.05-0.061$ & \\
\hline \multirow{2}{*}{\multicolumn{4}{|c|}{$\begin{array}{l}\text { Microstomus kitt } \\
\text { (lemon sole) }\end{array}$}} \\
\hline & & & \\
\hline \multirow[t]{2}{*}{ Northeast Atlantic } & $\mathrm{Zn}$ & $2.6-2.9$ & $(32)$ \\
\hline & $\mathrm{Cu}$ & $0.19-0.38$ & \\
\hline \multirow{2}{*}{\multicolumn{4}{|c|}{$\begin{array}{l}\text { Molva dypterygia } \\
\text { (blue ling) }\end{array}$}} \\
\hline & & & \\
\hline \multirow[t]{8}{*}{ West Scotland } & As & $1.84-13.09$ & (30) \\
\hline & $\mathrm{Cd}$ & $<0.002-0.004$ & \\
\hline & $\mathrm{Cu}$ & $0.10-0.41$ & \\
\hline & $\mathrm{Pb}$ & $<0.002-0.008$ & \\
\hline & As & $<0.02-32.44$ & \\
\hline & $\mathrm{Cd}$ & $<0.55-1.59$ & \\
\hline & $\mathrm{Cu}$ & $<1.00-7.10$ & \\
\hline & $\mathrm{Pb}$ & $<0.05-0.336$ & \\
\hline \multirow{2}{*}{\multicolumn{4}{|c|}{$\begin{array}{l}\text { Molva molva } \\
\text { (ling) }\end{array}$}} \\
\hline & & & \\
\hline \multirow[t]{2}{*}{ Northeast Atlantic } & $\mathrm{Zn}$ & $2.7-3.6$ & $(32)$ \\
\hline & $\mathrm{Cu}$ & $0.13-0.22$ & \\
\hline \multirow{2}{*}{\multicolumn{4}{|c|}{$\begin{array}{l}\text { Pagellus acarne } \\
\text { (axillary seabream) }\end{array}$}} \\
\hline & & & \\
\hline \multirow[t]{5}{*}{ Portuguese coast } & $\mathrm{Cr}$ & $0.15-0.425$ & ${ }^{1}(34)$ \\
\hline & $\mathrm{Ni}$ & $0.023-0.063$ & \\
\hline & $\mathrm{Hg}$ & $0.22-0.96$ & \\
\hline & $\mathrm{Pb}$ & $0.0025-0.018$ & \\
\hline & $\mathrm{Cd}$ & $0.0025-0.01$ & \\
\hline \multicolumn{4}{|l|}{ Pagellus bogaraveo } \\
\hline \multicolumn{4}{|l|}{ (black spot or red seabream) } \\
\hline \multirow[t]{5}{*}{ Portuguese coast } & $\mathrm{Cr}$ & $0.15-0.43$ & ${ }^{1}(34)$ \\
\hline & $\mathrm{Ni}$ & $0.023-0.063$ & \\
\hline & $\mathrm{Hg}$ & $0.22-0.96$ & \\
\hline & $\mathrm{Pb}$ & $0.0025-0.018$ & \\
\hline & $\mathrm{Cd}$ & $0.0025-0.01$ & \\
\hline \multicolumn{4}{|l|}{ Phycis phycis } \\
\hline (forkbeard) & & & \\
\hline
\end{tabular}




\begin{tabular}{|c|c|c|c|}
\hline $\begin{array}{l}\text { Specie, origin and tissue (muscle when not } \\
\text { specified) }\end{array}$ & Pollutant & Concentration (mg/kg ww) & Reference \\
\hline \multirow[t]{5}{*}{ Portuguese coast } & $\mathrm{Cr}$ & $0.18-0.325$ & ${ }^{1}(34)$ \\
\hline & $\mathrm{Ni}$ & $0.02-0.035$ & \\
\hline & $\mathrm{Hg}$ & $0.14-0.59$ & \\
\hline & $\mathrm{Pb}$ & $<0.008$ & \\
\hline & $\mathrm{Cd}$ & $0.0025-0.013$ & \\
\hline \multicolumn{4}{|l|}{ Pleuronectes platessa } \\
\hline \multicolumn{4}{|l|}{ (European plaice) } \\
\hline \multirow[t]{7}{*}{ Barents Sea } & $\mathrm{Cd}$ & 0.53 & ${ }^{1}(35)$ \\
\hline & $\mathrm{Hg}$ & 0.045 & \\
\hline & $\mathrm{Cu}$ & 3 & \\
\hline & $\mathrm{Zn}$ & 26.3 & \\
\hline & $\mathrm{Hg}$ & 0.06 & \\
\hline & $\mathrm{Cu}$ & 0.68 & \\
\hline & $\mathrm{Zn}$ & 5.75 & \\
\hline \multicolumn{4}{|l|}{$\begin{array}{l}\text { Pollachius virens } \\
\text { (saithe) }\end{array}$} \\
\hline \multirow[t]{6}{*}{ Barents Sea } & $\mathrm{Cd}$ & 0.058 & ${ }^{1}(35)$ \\
\hline & $\mathrm{Hg}$ & 0.005 & \\
\hline & $\mathrm{Cu}$ & 1.75 & \\
\hline & $\mathrm{Zn}$ & 9.75 & \\
\hline & $\mathrm{Hg}$ & 0.08 & \\
\hline & $\mathrm{Zn}$ & 7.0 & \\
\hline \multirow[t]{2}{*}{ Northeast Atlantic } & $\mathrm{Zn}$ & $3.7-4.5$ & (32) \\
\hline & $\mathrm{Cu}$ & $0.46-0.65$ & \\
\hline \multicolumn{4}{|l|}{$\begin{array}{l}\text { Sardina pilchardus } \\
\text { (sardine) }\end{array}$} \\
\hline \multirow[t]{4}{*}{ Catalonian markets } & As & $3.53-3.94$ & (6) \\
\hline & $\mathrm{Cd}$ & $0.002-0.01$ & \\
\hline & $\mathrm{Hg}$ & 0.07-0.09 & \\
\hline & $\mathrm{Pb}$ & $0.01-0.08$ & \\
\hline Spanish market & Hg (total) & 0.06 & (37) \\
\hline \multirow[t]{4}{*}{ Portuguese waters and markets } & $\mathrm{Hg}$ & $0.0116-0.0280$ & (8) \\
\hline & $\mathrm{Cd}$ & $0.0017-0.0151$ & \\
\hline & $\mathrm{Pb}$ & $0.0029-0.0569$ & \\
\hline & As & $0.8116-1.336$ & \\
\hline \multicolumn{4}{|l|}{ Scomber scombrus } \\
\hline \multicolumn{4}{|l|}{ (Atlantic mackerel) } \\
\hline \multirow[t]{2}{*}{ Northeast Atlantic } & $\mathrm{Zn}$ & $3.3-5.2$ & $(32)$ \\
\hline & $\mathrm{Cu}$ & $0.70-0.97$ & \\
\hline \multirow[t]{4}{*}{ Catalonian markets } & As & $1.73-7.47$ & (6) \\
\hline & $\mathrm{Cd}$ & $0.003-0.01$ & \\
\hline & $\mathrm{Hg}$ & $0.06-0.15$ & \\
\hline & $\mathrm{Pb}$ & $0.01-0.02$ & \\
\hline
\end{tabular}




\begin{tabular}{|c|c|c|c|}
\hline $\begin{array}{l}\text { Specie, origin and tissue (muscle when not } \\
\text { specified) }\end{array}$ & Pollutant & Concentration (mg/kg ww) & Reference \\
\hline Slovenia & $\mathrm{Hg}$ & $0.035-0.056$ & (7) \\
\hline \multicolumn{4}{|l|}{ Scyliorhinus caniculus } \\
\hline \multirow[t]{2}{*}{ Northeast Atlantic } & $\mathrm{Zn}$ & 8.5-8.7 & (32) \\
\hline & $\mathrm{Cu}$ & $0.50-0.53$ & \\
\hline \multicolumn{4}{|l|}{ Sepia spp } \\
\hline \multicolumn{4}{|l|}{ (cuttlefish) } \\
\hline \multirow[t]{4}{*}{ Catalonian markets } & As & $2.45-5.33$ & (6) \\
\hline & $\mathrm{Cd}$ & $0.01-0.09$ & \\
\hline & $\mathrm{Hg}$ & $0.04-0.08$ & \\
\hline & $\mathrm{Pb}$ & $0.01-0.10$ & \\
\hline \multicolumn{4}{|l|}{ Trachurus trachurus } \\
\hline \multicolumn{4}{|l|}{ (Atlantic horse mackerel) } \\
\hline \multirow[t]{4}{*}{ Mauritania } & $\mathrm{Cd}$ & 0.01 & ${ }^{1}(38)$ \\
\hline & $\mathrm{Cu}$ & 0.4 & \\
\hline & $\mathrm{Zn}$ & 10.5 & \\
\hline & $\mathrm{Hg}$ & 0.075 & \\
\hline \multirow[t]{4}{*}{ Portuguese waters and markets } & $\mathrm{Hg}$ & $0.0380-0.3371$ & (8) \\
\hline & $\mathrm{Cd}$ & $0.0030-0.0141$ & \\
\hline & $\mathrm{Pb}$ & $0.0031-0.0215$ & \\
\hline & As & $0.655-1.941$ & \\
\hline \multirow{2}{*}{\multicolumn{4}{|c|}{$\begin{array}{l}\text { Trisopterus luscus } \\
\text { (pouting) }\end{array}$}} \\
\hline & & & \\
\hline \multirow[t]{7}{*}{ Northern Iberian shelf-liver } & $\mathrm{Cu}$ & $0.58-2.0$ & ${ }^{1}(36)$ \\
\hline & Zn & $2.0-6.25$ & \\
\hline & $\mathrm{Cr}$ & $0.11-0.89$ & \\
\hline & $\mathrm{Fe}$ & $17.0-29.5$ & \\
\hline & $\mathrm{Cd}$ & $0.005-0.085$ & \\
\hline & $\mathrm{Pb}$ & $0.0005-0.013$ & \\
\hline & $\mathrm{Hg}$ & $0.00025-0.0085$ & \\
\hline \multicolumn{4}{|l|}{ Zeus faber } \\
\hline \multicolumn{4}{|l|}{ (John dory) } \\
\hline \multirow[t]{2}{*}{ Northeast Atlantic } & $\mathrm{Zn}$ & 3.1 & (32) \\
\hline & $\mathrm{Cu}$ & $0.12-0.14$ & \\
\hline Morocco & $\mathrm{Hg}$ & 0.066 & (7) \\
\hline
\end{tabular}

${ }^{1}$ assuming wet/dry ratio of 0.25 
Table 2. POPs Levels in Atlantic Fish Species

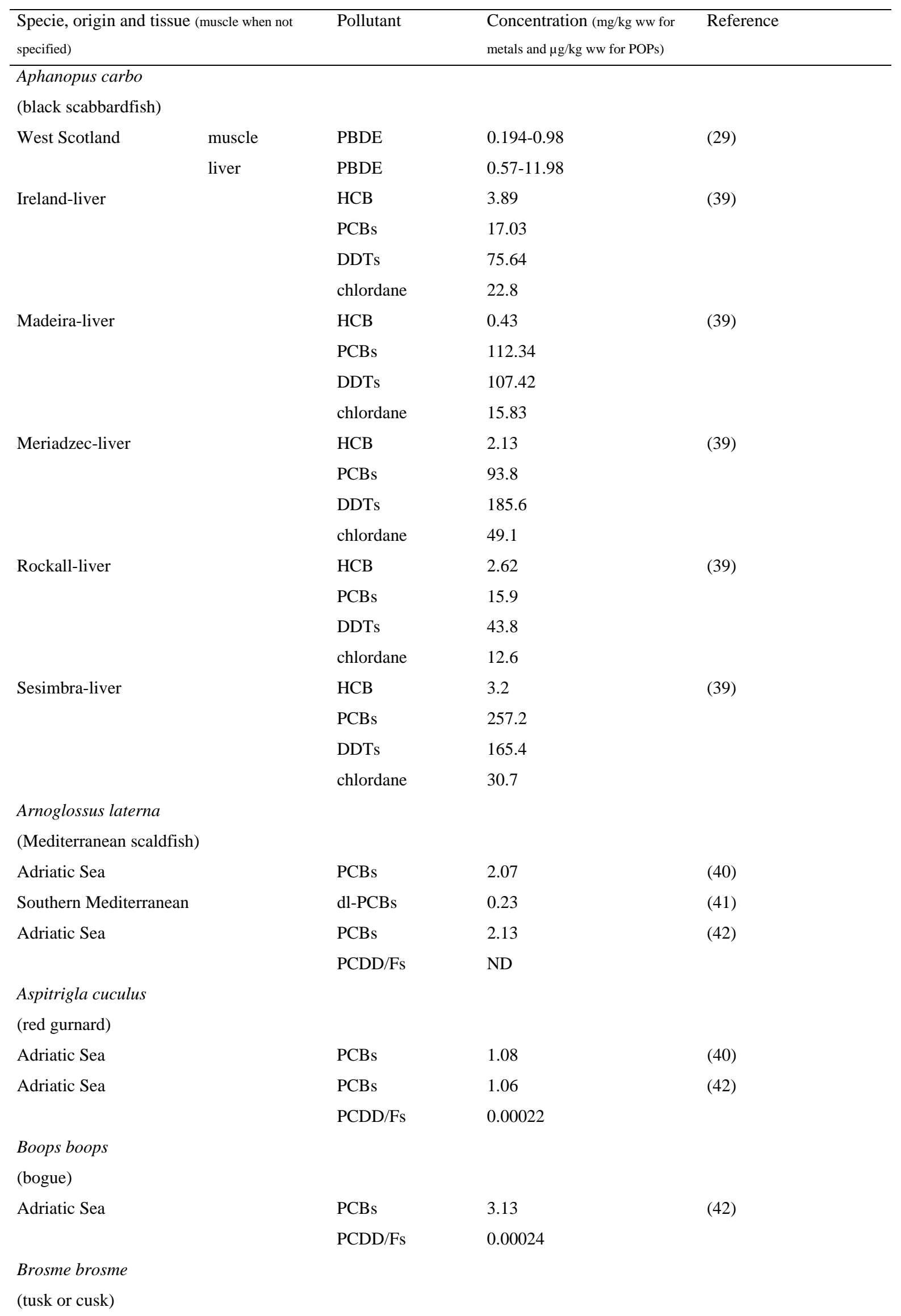




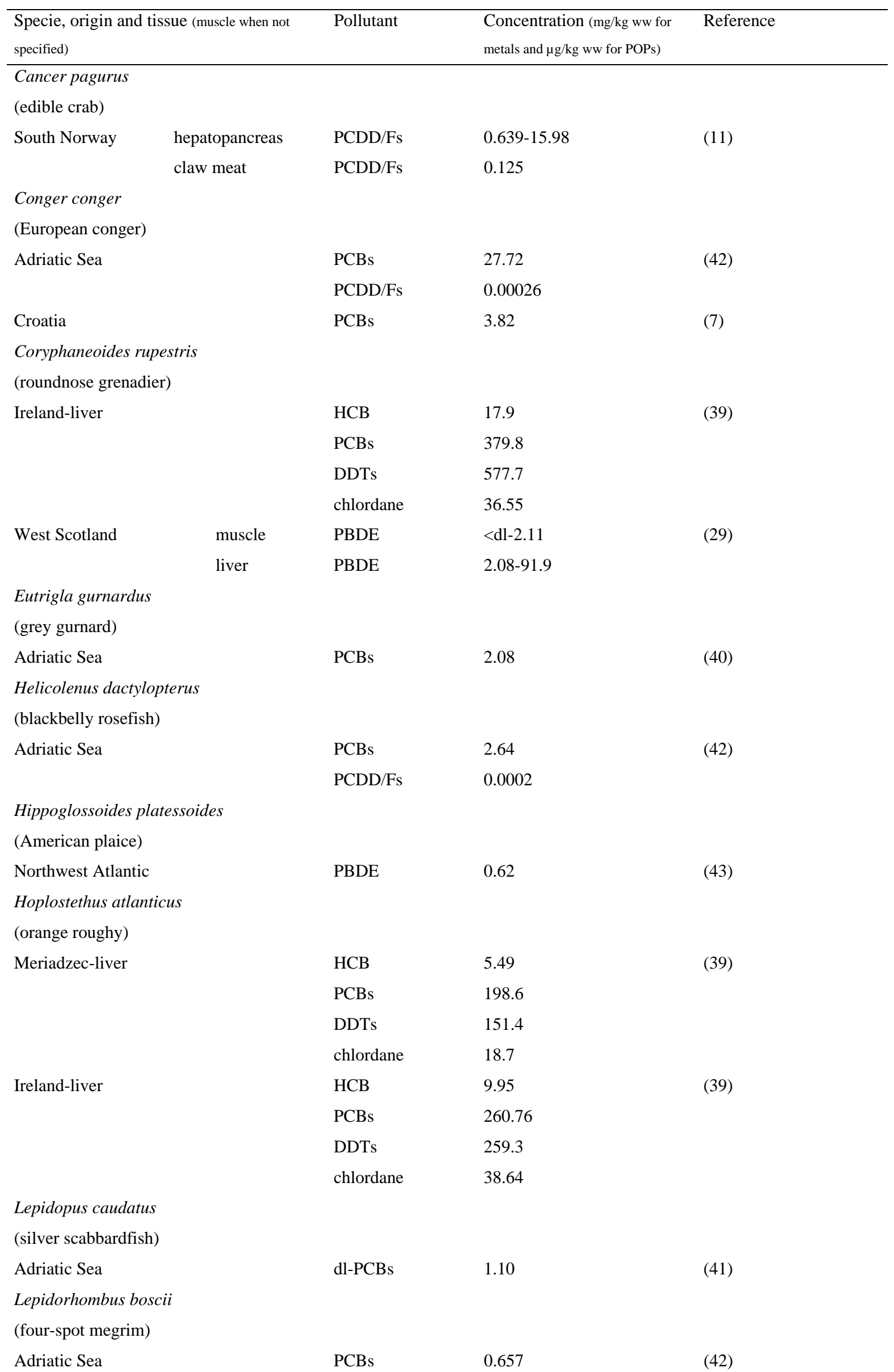




\begin{tabular}{|c|c|c|c|}
\hline $\begin{array}{l}\text { Specie, origin and tissue (muscle when not } \\
\text { specified) }\end{array}$ & Pollutant & $\begin{array}{l}\text { Concentration (mg } / \mathrm{kg} \mathrm{ww} \text { for } \\
\text { metals and } \mathrm{\mu g} / \mathrm{kg} \text { ww for POPs) }\end{array}$ & Reference \\
\hline $\begin{array}{l}\text { Lepidorhombus whiffiagonis } \\
\text { (megrim) }\end{array}$ & PCDD/Fs & ND & \\
\hline $\begin{array}{l}\text { Adriatic Sea } \\
\text { Loligo vulgaris } \\
\text { (European squid) } \\
\text { Lophius budegassa } \\
\text { (blackbellied angler) }\end{array}$ & PCBs & 2.08 & (40) \\
\hline Adriatic Sea & $\begin{array}{l}\text { PCBs } \\
\text { PCDD/Fs }\end{array}$ & $\begin{array}{l}0.245 \\
0.0000056\end{array}$ & $(42)$ \\
\hline $\begin{array}{l}\text { Lophius piscatorus } \\
\text { (monkfish) }\end{array}$ & & & \\
\hline Spanish Atlantic Southwest coast & $\begin{array}{l}\text { PCBs } \\
\text { PCDD/Fs }\end{array}$ & $\begin{array}{l}2.512-3.112 \\
0.00033-0.00086\end{array}$ & (44) \\
\hline $\begin{array}{l}\text { North Sea } \\
\text { Croatia }\end{array}$ & $\begin{array}{l}\text { dl-PCBs } \\
\text { PCBs }\end{array}$ & $\begin{array}{l}0.09 \\
1.8-3.3\end{array}$ & $\begin{array}{l}(41) \\
(7)\end{array}$ \\
\hline $\begin{array}{l}\text { Merluccius merluccius } \\
\text { (hake) }\end{array}$ & & & \\
\hline Bay of Biscay & $\mathrm{PCDD} / \mathrm{F}$ & 0.000086 & (5) \\
\hline Southern Italy & $\begin{array}{l}\text { HCB } \\
\text { DDTs } \\
\text { PCBs }\end{array}$ & $\begin{array}{l}<\mathrm{dl}-0.48 \\
0.98-9.2 \\
6.72-101.3\end{array}$ & (45) \\
\hline Adriatic Sea & $\begin{array}{l}\text { PCBs } \\
\text { PCDD/Fs }\end{array}$ & $\begin{array}{l}3.41 \\
0.00008\end{array}$ & $(42)$ \\
\hline $\begin{array}{l}\text { Croatia } \\
\text { Atlantic Ocean } \\
\text { Molva molva } \\
\text { (ling) }\end{array}$ & $\begin{array}{l}\text { PCBs } \\
\text { dl-PCBs }\end{array}$ & $\begin{array}{l}2.7-4.6 \\
1.33\end{array}$ & $\begin{array}{l}(7) \\
(41)\end{array}$ \\
\hline Ireland-liver & $\begin{array}{l}\text { HCB } \\
\text { PCBs } \\
\text { DDTs } \\
\text { chlordane }\end{array}$ & $\begin{array}{l}31.19 \\
610.8 \\
505.24 \\
160.11\end{array}$ & (39) \\
\hline $\begin{array}{l}\text { Mora moro } \\
\text { (common mora) }\end{array}$ & & & \\
\hline Mediterranean Sea-liver & $\begin{array}{l}\text { DDTs } \\
\text { PCBs }\end{array}$ & $\begin{array}{l}745-1630 \\
736-5490\end{array}$ & (46) \\
\hline $\begin{array}{l}\text { Mustelus asterias } \\
\text { (starry smooth-hound) }\end{array}$ & & & \\
\hline $\begin{array}{l}\text { North Sea } \\
\text { Pagellus acarne } \\
\text { (axillary seabream) }\end{array}$ & dl-PCBs & 7.60 & (41) \\
\hline $\begin{array}{l}\text { Adriatic Sea } \\
\text { Phycis blennoides }\end{array}$ & PCBs & 1.52 & (40) \\
\hline
\end{tabular}




\begin{tabular}{|c|c|c|c|}
\hline $\begin{array}{l}\text { Specie, origin and tissue (muscle when not } \\
\text { specified) }\end{array}$ & Pollutant & $\begin{array}{l}\text { Concentration (mg/kg ww for } \\
\text { metals and } \mu \mathrm{g} / \mathrm{kg} \text { ww for POPs) }\end{array}$ & Reference \\
\hline \multicolumn{4}{|l|}{ (greater forkbeard) } \\
\hline \multirow[t]{2}{*}{ Mediterranean Sea-liver } & DDTs & 214 & (47) \\
\hline & PCBs & 350 & \\
\hline \multirow[t]{2}{*}{ Adriatic Sea } & PCBs & 0.0011 & $(42)$ \\
\hline & $\mathrm{PCDD} / \mathrm{Fs}$ & 0.0000096 & \\
\hline \multicolumn{4}{|l|}{ Pleuronectes platessa } \\
\hline \multicolumn{4}{|l|}{ (European plaice) } \\
\hline North Sea & dl-PCBs & 0.34 & $(41)$ \\
\hline \multicolumn{4}{|l|}{ Pollachius virens } \\
\hline \multicolumn{4}{|l|}{ (saithe) } \\
\hline North Sea & $\mathrm{PCDD} / \mathrm{F}$ & 0.098 & (5) \\
\hline Norway & $\mathrm{PCDD} / \mathrm{F}$ & 0.025 & (5) \\
\hline Mediterraneum Sea & dl-PCBs & 0.47 & $(41)$ \\
\hline \multicolumn{4}{|l|}{ Raja clavata } \\
\hline \multicolumn{4}{|l|}{ (thornback ray) } \\
\hline North Sea & dl-PCBs & 0.15 & $(41)$ \\
\hline \multicolumn{4}{|l|}{ Sardina pilchardus } \\
\hline \multicolumn{4}{|l|}{ (sardine) } \\
\hline Bay of Biscay & $\mathrm{PCDD} / \mathrm{F}$ & 0.603 & (5) \\
\hline \multirow[t]{2}{*}{ Spanish market } & $\mathrm{PCDD} / \mathrm{Fs}$ & $0.00145-0.00239$ & $(48)$ \\
\hline & PCBs & 0.049-0.0652 & \\
\hline \multirow[t]{2}{*}{ Spanish Atlantic Southwest coast } & PCBs & 20.9-23.8 & (44) \\
\hline & $\mathrm{PCDD} / \mathrm{Fs}$ & 0.00084-0.00119 & \\
\hline Adriatic Sea & dl-PCBs & 0.88 & $(41)$ \\
\hline \multicolumn{4}{|l|}{ Scomber scombrus } \\
\hline \multicolumn{4}{|l|}{ (Atlantic mackerel) } \\
\hline Bay of Biscay & $\mathrm{PCDD} / \mathrm{F}$ & 0.317 & (5) \\
\hline North Sea & $\mathrm{PCDD} / \mathrm{F}$ & 0.330 & (5) \\
\hline \multirow[t]{3}{*}{ North Ionan Sea-liver } & HCB & ND-6.07 & (49) \\
\hline & DDE & $0.25-104$ & \\
\hline & PCBs & $0.1-158$ & \\
\hline \multirow[t]{3}{*}{ Southern Italy } & HCB & $<\mathrm{dl}-2.83$ & (45) \\
\hline & DDTs & $<\mathrm{dl}-23.8$ & \\
\hline & PCBs & $2.54-237.8$ & \\
\hline \multirow[t]{2}{*}{ Northwest Atlantic } & PBDE & 7.11 & (43) \\
\hline & HBCD & 1.44 & \\
\hline Slovenia & PCBs & 8.4-17.4 & (7) \\
\hline \multicolumn{4}{|l|}{ Trachurus mediterraneus } \\
\hline \multicolumn{4}{|l|}{ (Mediterranean horse mackerel) } \\
\hline \multirow[t]{2}{*}{ Adriatic Sea } & PCBs & 5.2 & $(42)$ \\
\hline & PCDD/Fs & 0.000062 & \\
\hline
\end{tabular}

Trachurus trachurus

(Atlantic horse mackerel) 


\begin{tabular}{llll}
\hline $\begin{array}{l}\text { Specie, origin and tissue (muscle when not } \\
\text { specified) }\end{array}$ & Pollutant & $\begin{array}{l}\text { Concentration }(\mathrm{mg} / \mathrm{kg} \text { ww for } \\
\text { metals and } \mu \mathrm{g} / \mathrm{kg} \mathrm{ww} \text { for POPs) }\end{array}$ & Reference \\
\hline Adriatic Sea & PCBs & 6.15 & $(42)$ \\
PCDD/Fs & ND \\
$\begin{array}{l}\text { Trigla lyra } \\
\text { (piper gurnard) } \\
\begin{array}{l}\text { Adriatic Sea } \\
\text { PCBs }\end{array}\end{array}$ & PCBs & 0.70 & $(40)$ \\
\hline
\end{tabular}


Table 3. Pollutant content in Fish By-Products

\begin{tabular}{|c|c|c|c|}
\hline Type and Origin & Pollutant & Concentration (ng/g) & Reference \\
\hline \multirow[t]{2}{*}{ Fish oil -Mixed (no salmon) } & PCDD/Fs & 0.00055 & (13) \\
\hline & PBDEs & 0.887 & \\
\hline \multirow[t]{2}{*}{ Fish oil-Mixed (including salmon) } & $\mathrm{PCDD} / \mathrm{Fs}$ & 0.00157 & $(13)$ \\
\hline & PBDEs & 0.898 & \\
\hline \multirow[t]{2}{*}{ Fish oil-Salmon } & $\mathrm{PCDD} / \mathrm{Fs}$ & 0.0072 & (13) \\
\hline & PBDEs & 3.260 & \\
\hline \multirow[t]{2}{*}{ Fish oil-Shark } & $\mathrm{PCDD} / \mathrm{Fs}$ & 0.139 & $(13)$ \\
\hline & PBDEs & 57.7 & \\
\hline \multirow[t]{2}{*}{ Fish oil-Menhaden } & PCDD/Fs & 0.0818 & $(13)$ \\
\hline & PBDEs & 50.9 & \\
\hline Fish oil- Fish processing industry & HCB & 12 & $(51)$ \\
\hline \multirow[t]{2}{*}{ blend-Baltic Sea } & DDTs & 337 & \\
\hline & PCBs & 197 & \\
\hline \multirow[t]{4}{*}{ Fish oil-unknown } & $\mathrm{HCH}$ & 11.9 & $(52)$ \\
\hline & DDTs & 30.0 & \\
\hline & PCB & 74.0 & \\
\hline & PBDEs & 12.7 & \\
\hline \multirow[t]{4}{*}{ Fish feed-Scottish source } & $\mathrm{HCH}$ & 30.4 & $(52)$ \\
\hline & DDTs & 47.9 & \\
\hline & PCBs & 157.3 & \\
\hline & PBDEs & 16.2 & \\
\hline \multirow[t]{11}{*}{ Fish meal-Peru } & PCDDs & 0.132 & $(22)$ \\
\hline & PCDFs & 0.058 & \\
\hline & DL-PCBs & 0.17 & \\
\hline & non DL-PCBs & 2.0 & \\
\hline & PBDEs & 0.068 & \\
\hline & НCB & 0.18 & \\
\hline & DDTs & 1.9 & \\
\hline & As & 3 (mg/kg) & \\
\hline & $\mathrm{Hg}$ & 0.045 (mg/kg) & \\
\hline & $\mathrm{Cd}$ & $1.2(\mathrm{mg} / \mathrm{kg})$ & \\
\hline & $\mathrm{Pb}$ & 0.087 (mg/kg) & \\
\hline \multirow[t]{7}{*}{ Fish oil-Norway } & PCDDs & 2.48 & $(22)$ \\
\hline & PCDFs & 5.2 & \\
\hline & DL-PCBs & 21 & \\
\hline & non DL-PCBs & 133 & \\
\hline & PBDEs & 26 & \\
\hline & HCB & 40 & \\
\hline & DDTs & 254 & \\
\hline \multirow[t]{3}{*}{ Krill meal-Norway } & PCDDs & 0.048 & $(22)$ \\
\hline & PCDFs & 0.060 & \\
\hline & DL-PCBs & 0.072 & \\
\hline
\end{tabular}




\begin{tabular}{llll}
\hline Type and Origin & Pollutant & Concentration (ng/g) & Reference \\
\hline & non DL-PCBs & 1.3 & \\
& PBDEs & 0.047 & \\
& HCB & 1.1 & \\
& DDTs & - & $(53)$ \\
Fish oil for feed- different sources & HBCD & $3.34-26.8$ & (53) \\
Fish oil for food-different sources & HBCD & $0.19-4.19$ & \\
\hline
\end{tabular}

